\title{
Impact of climate variability and land use changes on global biogenic volatile organic compound emissions
}

\author{
J. Lathière ${ }^{1}$, D. A. Hauglustaine ${ }^{1}$, A. D. Friend ${ }^{1}$, N. De Noblet-Ducoudré ${ }^{1}$, N. Viovy ${ }^{1}$, and G. A. Folberth ${ }^{2}$ \\ ${ }^{1}$ Laboratoire des Sciences du Climat et de l'Environnement (LSCE), Gif-sur-Yvette, France \\ ${ }^{2}$ School of Earth and Ocean Sciences (SEOS), University of Victoria, Victoria, Canada
}

Received: 19 July 2005 - Published in Atmos. Chem. Phys. Discuss.: 25 October 2005

Revised: 28 February 2006 - Accepted: 22 April 2006 - Published: 20 June 2006

\begin{abstract}
A biogenic emissions scheme has been incorporated in the global dynamic vegetation model ORCHIDEE (Organizing Carbon and Hydrology in Dynamic EcosystEms) in order to calculate global biogenic emissions of isoprene, monoterpenes, methanol, acetone, acetaldehyde, formaldehyde and formic and acetic acids. Important parameters such as the leaf area index are fully determined by the global vegetation model and the influences of light extinction (for isoprene emissions) and leaf age (for isoprene and methanol emissions) are also taken into account. We study the interannual variability of biogenic emissions using the satellite-based climate forcing ISLSCP-II as well as relevant $\mathrm{CO}_{2}$ atmospheric levels, for the 1983-1995 period. Mean global emissions of $460 \mathrm{TgC} / \mathrm{yr}$ for isoprene, $117 \mathrm{TgC} / \mathrm{yr}$ for monoterpenes, $106 \mathrm{TgC} / \mathrm{yr}$ for methanol and $42 \mathrm{TgC} / \mathrm{yr}$ for acetone are predicted. The mean global emission of all biogenic compounds is $752 \pm 16 \mathrm{TgC} / \mathrm{yr}$ with extremes ranging from $717 \mathrm{TgC} / \mathrm{yr}$ in 1986 to $778 \mathrm{TgC} / \mathrm{yr}$ in 1995 , that is a $8.5 \%$ increase between both. This variability differs significantly from one region to another and among the regions studied, biogenic emissions anomalies were the most variable in Europe and the least variable in Indonesia (isoprene and monoterpenes) and North America (methanol). Two scenarios of land use changes are considered using the 1983 climate and atmospheric $\mathrm{CO}_{2}$ conditions, to study the sensitivity of biogenic emissions to vegetation alteration, namely tropical deforestation and European afforestation. Global biogenic emissions are highly affected by tropical deforestation, with a $29 \%$ decrease in isoprene emission and a $22 \%$ increase in methanol emission. Global emissions are not significantly affected by European afforestation, but on a European scale, total biogenic VOCs emissions increase by $54 \%$.
\end{abstract}

Correspondence to: J. Lathière

(juliette.lathiere@cea.fr)

\section{Introduction}

The terrestrial biosphere is a major source of natural volatile organic compounds (VOCs). Isoprene and monoterpenes dominate biogenic emissions but other highly reactive chemical species, such as methanol, acetone, aldehydes and organic acids, are now also recognized to be emitted by the terrestrial vegetation at significant levels, as shown by several measurement campaigns (Kirstine et al., 1998; Schade and Goldstein, 2001; Villanueva-Fierro et al., 2004). Global VOCs emissions by the vegetation are $1150 \mathrm{TgC} / \mathrm{yr}$ (Guenther et al., 1995), corresponding to nearly $90 \%$ of global VOC emissions at the surface (including anthropogenic emissions).

Those biogenic compounds play a crucial role in tropospheric chemistry, from local to global scales, inducing increased or decreased ozone formation, depending on $\mathrm{NO}_{\mathrm{x}}$ levels (Fehsenfeld et al., 1992; Thunis and Cuvelier, 2000; Pun et al., 2002). Recently, Barket al. (2004) showed that isoprene photooxidation results in maximum ozone production rates for $\mathrm{NO}_{\mathrm{x}}$ concentrations in the range of about 1 $10 \mathrm{ppbv}$, a typical level of anthropogenically influenced rural environments. Wang and Shallcross (2000) used a global land-surface and chemistry-transport model to show that the inclusion of isoprene emissions, estimated at $530 \mathrm{TgC} / \mathrm{yr}$ for present day conditions, has a significant impact on ozone and oxidation products, such as peroxyacetyl nitrate (PAN), in both hemispheres. Their analysis indicated that the response of ozone to isoprene emissions was predominantly governed by the spatial and temporal variations in terrestrial vegetation, with a simulated ozone increase of about 4 ppbv over the oceans and about 8-12 ppbv over mid-latitude continental areas. Sanderson et al. (2003) illustrated the impact of climate change on both isoprene emissions and ozone levels. Based on a global isoprene emission increase from $484 \mathrm{TgC} / \mathrm{yr}$ for the 1990 s to $615 \mathrm{TgC} / \mathrm{yr}$ for the 2090s, as a result of climate and vegetation distribution changes, the authors calculated an

Published by Copernicus GmbH on behalf of the European Geosciences Union. 
ozone increase by $10-20 \mathrm{ppbv}$ in some locations. They also noted that the changes in ozone levels were closely linked to changes in isoprene surface fluxes in regions such as the eastern U.S. or southern China. However, this effect was much less marked over the Amazon region and Africa because of lower levels of nitrogen oxides.

In addition to their importance for gas phase chemistry, the involvement of biogenic VOCs in tropospheric aerosols formation, first suggested by Went (1960), has lately been demonstrated (Griffin et al., 1999), and enforces the importance of taking into account biogenic VOC in both tropospheric gas phase reactions and particulate formation. Assuming an aerosol yield from the oxidation of biogenic VOC other than isoprene (monoterpenes and other VOC) between 5\% and 40\%, Andreae and Crutzen (1997) suggested that the secondary organic aerosols (SOA) formation could range between 30 and $270 \mathrm{Tg}$ of organic matter per year. More recently, Tsigaridis and Kanakidou (2003) estimated, using a global chemistry-transport model, that the production of SOA from biogenic VOC might range from 2.5 to $44.5 \mathrm{Tg} / \mathrm{yr}$ Furthermore, Kanakidou et al. (2000) estimated that the production of SOA from biogenic VOCs increased from 17$28 \mathrm{Tg} / \mathrm{yr}$ in preindustrial times to $61-79 \mathrm{Tg} / \mathrm{yr}$ for present day conditions, which was attributed to an increase in ozone and primary organic aerosol from anthropogenic sources. In addition to the recognized role of monoterpenes SOA formation (Kavouras et al., 1999; Sotiropoulou et al., 2004), recent studies (Limbeck et al., 2003; Claeys et al., 2004) also suggest the importance of isoprene in aerosol formation, leading to $2 \mathrm{Tg}$ of organic matter per year (Claeys et al., 2004).

Key parameters, such as environmental conditions (mainly temperature and radiation), vegetation type and foliar area, constrain biogenic emissions, thus making them very sensitive to climate and land use changes. In addition, vegetation is not only influenced by climate change but also human activity and development, such as urbanization and agriculture expansion. Mainly initiated by Guenther et al. (1995), global biogenic emissions modeling now benefits from dynamic vegetation models, allowing the calculation of biogenic emissions for the present day, as well as studying their possible future evolution in response to vegetation and climate changes (Levis et al., 2003; Sanderson et al., 2003; Naik et al., 2004; Lathière et al., 2005). The History Database of the Global Environment (HYDE), developed by Goldewijk (2001) to estimate global land use changes over the past 300 years (1700-1990), based on historical statistical inventories and spatial analysis techniques, suggests a global increase of cropland area from $265 \times 10^{6}$ ha in 1700 to $1471 \times 10^{6}$ ha in 1990 , and a more than six fold increase of pasture area from $524 \times 10^{6}$ to $3451 \times 10^{6}$ ha. Important regional differences are found: most of the land use change occurred during the 19th century in temperate regions of Canada, the United States, Russia and Oceania, whereas in most of the tropical regions, the largest rate of land use conversion occurred at the end of the last century. A study of the impact of deforestation in Amazonia on tropospheric chemistry (Ganzeveld and Lelieveld, 2004), replacing tropical rainforest by pasture, predicted a large decrease in maximum isoprene emission fluxes, from $12 \times 10^{15}$ to $1.2 \times 10^{15}$ molecules $\mathrm{m}^{-2} \mathrm{~s}^{-1}\left(=11.9 \times 10^{-11} \mathrm{kgC} / \mathrm{m}^{2} / \mathrm{s}\right)$ due to a decrease in the isoprene emission factor and in the foliar density. Furthermore, a large reduction in the diurnal ozone deposition velocity and an increase of nocturnal soil deposition were predicted Steiner et al. (2002) estimated that in East Asia, the human-induced land-cover changes, characterized by the conversion of about $30 \%$ of the land area from forests to cropland, led to a decrease of $30 \%$ in isoprene and $40 \%$ in monoterpenes annual emissions. On the other hand, forest restoration efforts are done in some regions such as boreal and temperate zones of North America and western Europe, leading to an increase in forest cover (Stanturf and Madsen, 2002), which could also affect significantly biogenic emission levels and tropospheric chemistry.

The main goal of our work is to study the sensitivity of global biogenic emissions to, first, climate and atmospheric $\mathrm{CO}_{2}$ interannual variability and, second, to vegetation distribution changes. We have incorporated a biogenic emission scheme in the dynamic global vegetation model ORCHIDEE to calculate not only isoprene and monoterpenes emissions but also methanol, acetone, acetaldehyde, formaldehyde, formic and acetic acids.

In Sect. 2 of this paper, we describe the interactive biogenic emission and vegetation model used in our study, as well as details of the simulations. Global mean estimates for the 1983-1995 period are given in Sect. 3 and compared to the results of other studies. Analysis of the impact of climate and $\mathrm{CO}_{2}$ interannual variability from 1983 to 1995 on the simulated biogenic VOC emissions is presented in Sect. 4. Finally, two scenarios of land use change, tropical deforestation and European afforestation, are considered in Sect. 5 to analyse the sensitivity of biogenic emissions to the vegetation distribution alteration.

\section{The interactive biogenic emission and vegetation model}

\subsection{General description}

A biogenic emission scheme, based on Guenther et al. (1995) parameterizations, has been incorporated into the dynamic global vegetation model ORCHIDEE (Organizing Carbon and Hydrology in Dynamic EcosystEms) (Krinner et al., 2005). This terrestrial biosphere model consists of the surface-vegetation-atmosphere transfer scheme SECHIBA (Schématisation des échanges hydriques à l'interface biosphere-atmosphère), (Ducoudré et al., 1993; De Rosnay and Polcher, 1998) and of the carbon module STOMATE (Saclay-Toulouse-Orsay Model for the Analysis of Terrestrial Ecosystems), which includes the dynamic 
vegetation component of the LPJ (Lund-Potsdam-Jena) dynamic model (Sitch et al., 2003).

SECHIBA calculates processes characterized by short time-scales, ranging from a few minutes to hours, such as energy and water exchanges between the atmosphere and the terrestrial biosphere, photosynthesis, as well as the soil water budget. SECHIBA has a time step of $30 \mathrm{~min}$ in order to simulate the diurnal cycle of the terrestrial biosphere. STOMATE treats daily processes such as carbon allocation, litter decomposition, soil carbon dynamics, phenology, maintenance and growth respiration. Important parameterizations, allowing the dynamic simulation of vegetation distribution, have been taken from the global model LPJ: processes such as fire, sapling establishment, light competition, tree mortality and climatic criteria for the introduction and elimination of plant functional types are integrated into ORCHIDEE, with a time step of one year.

In the ORCHIDEE model, the land surface is described as a mosaic of twelve plant functional types (PFTs) and bare soil (Fig. 1). The definition of PFT is based on ecological parameters such as plant physiognomy (tree or grass), leaves (needleleaf or broadleaf), phenology (evergreen, summergreen or raingreen) and photosynthesis type for crops and grasses $\left(\mathrm{C}_{3}\right.$ or $\left.\mathrm{C}_{4}\right)$. Relevant biophysical and biogeochemical parameters are prescribed for each PFT (Krinner et al., 2005). This distinction is of great importance since the nature and the amount of the biogenic VOCs emitted are very different from one vegetation type to another. In the current version of ORCHIDEE there is no explicit terrestrial nitrogen cycle. However, nitrogen is implicitly taken into account in the photosynthesis and carbon allocation calculations. For carbon allocation, a nitrogen limitation is parameterized as a function of monthly soil moisture and temperature, because nitrogen availability of a plant depends on microbial activity in soil, and thus on soil moisture and temperature. Photosynthesis is parameterized as an exponential function decreasing with canopy depth, with an asymptotic minimum limit of $30 \%$ of the maximum efficiency, to take into account vertical variation of photosynthetic capacity based on leaf nitrogen content. Leaf onset and senescence are calculated, depending on the PFT, by applying warmth and/or moisture stress criteria to the meteorological conditions. Carbon allocation to leaves, and to other compartments such as roots and sap wood, depends on external constraints such as temperature, moisture or light. The more stress a tissue will suffer, the more carbon it receives. In addition, a maximum leaf area index (LAI) value, above which no carbon will be allocated to leaves, is prescribed for each PFT: $7 \mathrm{~m}^{2} / \mathrm{m}^{2}$ for tropical trees, $5 \mathrm{~m}^{2} / \mathrm{m}^{2}$ for temperate trees, 3 and $4.5 \mathrm{~m}^{2} / \mathrm{m}^{2}$ for boreal forests, $2.5 \mathrm{~m}^{2} / \mathrm{m}^{2}$ for grasses and $5 \mathrm{~m}^{2} / \mathrm{m}^{2}$ for crops (Fig. 1). The leaf photosynthetic efficiency varies during its life cycle: small when the leaf is young, it increases quickly with the leaf age up to a maximum value, lasting until the leaf age equals half its critical value, and then decreases. To take into account this feature, a leaf age structure has been imple-

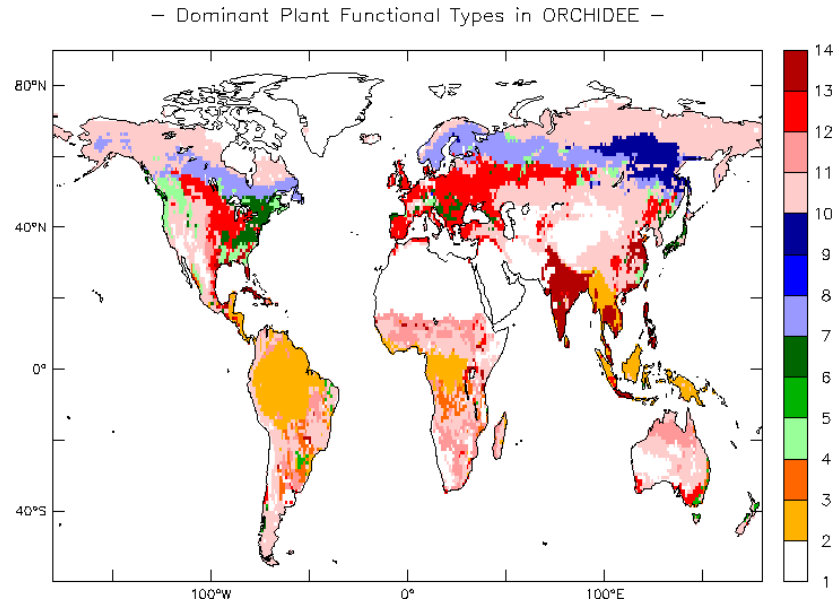

\begin{tabular}{clcc}
\hline No. & PFT Description & $\begin{array}{c}\text { Maximum LAI } \\
\left(\mathrm{m}^{2} / \mathrm{m}^{2}\right)\end{array}$ & $\begin{array}{c}\text { Critical leaf age } \\
(\text { days })\end{array}$ \\
\hline 1 & $\begin{array}{l}\text { Bare soil } \\
\text { Tropical broadleaf ever- } \\
\text { green tree }\end{array}$ & 7 & 730 \\
3 & $\begin{array}{l}\text { Tropical broadleaf rain- } \\
\text { green tree }\end{array}$ & 7 & 180 \\
4 & $\begin{array}{l}\text { Temperate needleleaf ev- } \\
\text { ergreen tree }\end{array}$ & 5 & 910 \\
5 & $\begin{array}{l}\text { Temperate broadleaf ev- } \\
\text { ergreen tree }\end{array}$ & 5 & 730 \\
6 & $\begin{array}{l}\text { Temperate } \\
\text { summergreen tree }\end{array}$ & 5 & 180 \\
7 & $\begin{array}{l}\text { Boreal needleleaf ever- } \\
\text { green tree }\end{array}$ & 4.5 & 910 \\
8 & $\begin{array}{l}\text { Boreal broadleaf sum- } \\
\text { mergreen tree }\end{array}$ & 4.5 & 180 \\
9 & $\begin{array}{l}\text { Boreal needleleaf sum- } \\
\text { mergreen tree }\end{array}$ & 3 & 180 \\
10 & $\begin{array}{l}\text { C3 Grass } \\
\text { C4 Grass }\end{array}$ & 2.5 & 120 \\
12 & $\begin{array}{l}\text { C3 Agriculture } \\
\text { C4 Agriculture }\end{array}$ & 2.5 & 120 \\
13 & 5 & 120 \\
\hline & & 5 & 120 \\
\hline
\end{tabular}

Fig. 1. Dominant plant functional types (PFTs) in ORCHIDEE, corresponding maximum leaf area index (LAI in $\mathrm{m}^{2} / \mathrm{m}^{2}$ ) and critical leaf age (in days).

mented in the ORCHIDEE model. In the current model version, 4 leaf age classes are considered, each corresponding to various leaf efficiency regimes and of equal duration (=critical leaf age/number of leaf age classes). The critical leaf age is 910 days for needleleaf evergreen trees, 730 days for broadleaf evergreen trees, 180 days for raingreen and summergreen trees and 120 days for grasses and crops. This feature is critical in accounting for the leaf age influence on biogenic emissions (MacDonald and Fall, 1993; Guenther et al., 2000).

ORCHIDEE can either be forced by archived climate fields or driven by a general circulation model and can run in various modes, depending on the activated model components. For instance, the natural PFT distribution can either be 


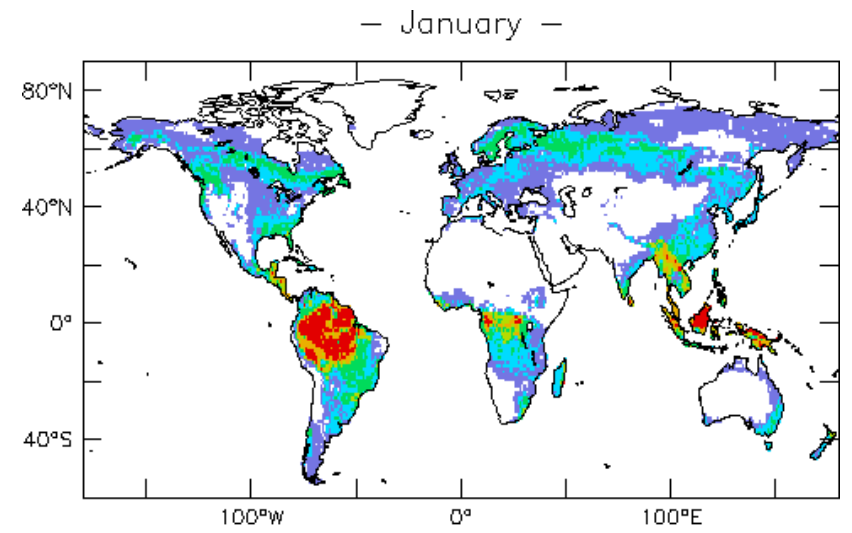

- July -

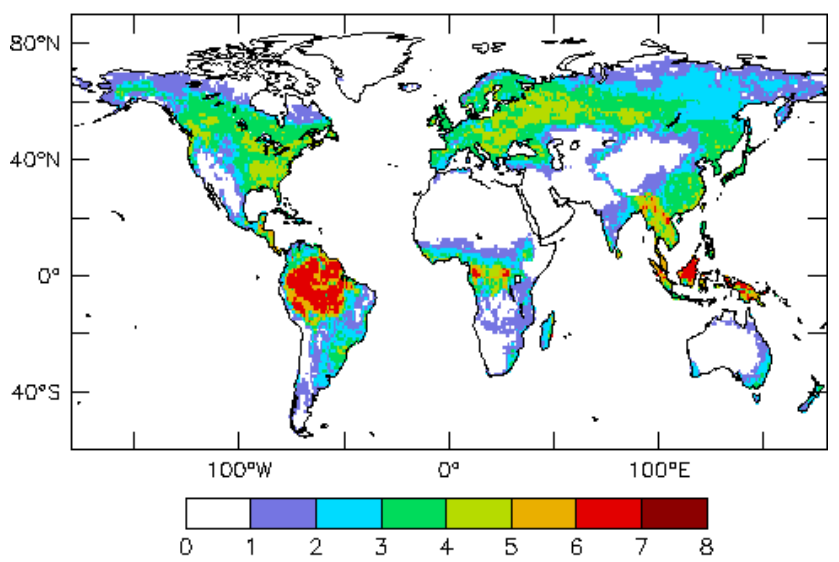

Fig. 2. Monthly mean Leaf Area Index (LAI, $\mathrm{m}^{2} / \mathrm{m}^{2}$ ) calculated by ORCHIDEE for January and July.

prescribed from an inventory (static mode, LPJ not activated) or entirely simulated by the model (dynamic mode, LPJ activated), depending on climate conditions. The fraction of the grid box occupied by agricultural PFTs is always prescribed so that crop extent is not affected by the dynamic vegetation change. The atmospheric $\mathrm{CO}_{2}$ levels influence photosynthesis, and consequently, the LAI, and can thus indirectly affect VOC biogenic emissions. It is thus really important to consider the relevant $\mathrm{CO}_{2}$ atmospheric level for each year and take into account its evolution throughout the period analysed.

Validation studies showed that the ORCHIDEE model accurately simulates water, energy and carbon exchanges, as well as vegetation processes on short and long time-scales. A more detailed description of the ORCHIDEE model and its validation is presented in Krinner et al. (2005), and its good skills for interannual variability have been illustrated by Ciais et al. (2005).

\subsection{Biogenic emission model}

In addition to isoprene and monoterpenes, we also explicitly estimate the emissions of methanol, acetone, acetaldehyde, formaldehyde, formic and acetic acids, which are usually considered as a family of compounds and estimated as bulk emissions. VOC biogenic emissions are calculated every 30 minutes, based on the Guenther et al. (1995) parameterizations, and integrate additional feature such as the leaf age influence on isoprene and methanol emissions.

The generic formula is:

$F=L A I \times s \times E_{f} \times C_{T} \times C_{L} \times L_{a}$

where $\mathrm{F}$ is the flux of the considered biogenic species, given in $\mu \mathrm{gC} / \mathrm{m}^{2} / \mathrm{h}$ and LAI the leaf area index in $\mathrm{m}^{2} / \mathrm{m}^{2}$, calculated at each time step by the model (Fig. 2). The specific leaf weight $\mathrm{s}$ in $\mathrm{gdm} / \mathrm{m}^{2}$ (dm: dry matter) is prescribed in ORCHIDEE depending on the considered PFT. $\mathrm{E}_{f}$ is the emission factor in $\mu \mathrm{gC} / \mathrm{gdm} / \mathrm{h}$ prescribed for each PFT and biogenic species (Table 1). Isoprene, and monoterpenes emission factors are based on Guenther et al. (1995) and adapted to the PFTs considered in ORCHIDEE. For methanol, we use emission factors from Guenther et al. (2000) and MacDonald and Fall (1993), crops being the highest methanol emitters. For the other VOCs (acetone, aldehydes and acids), we use emission factors from Kesselmeier and Staudt (1999) and Janson and De Serves (2001).

$\mathrm{C}_{T}$ (Eq. 2) and $\mathrm{C}_{L}$ (Eq. 3) are adjustment factors which account for the influence of leaf temperature and photosynthetically active radiation (PAR) on biogenic emissions and depend on the considered biogenic species. For isoprene, both light and temperature dependencies are considered and the radiation extinction inside the canopy is also taken into account. The leaf area index, used in Eq. (1), is divided into a sunlit and a shaded fraction and a separate calculation is applied to each to estimate the incident PAR flux, used in Eq. (3). The direct PAR is considered to only reach sunlit leaves whereas diffuse PAR is received by both sunlit and shaded leaves (Guenther et al., 1995). The total flux of isoprene is then the sum of emissions from both sunlit and shaded leaves. The PAR is calculated from the surface incident short-wave radiation given in the forcing file (see below). For other chemical species only a temperature dependency is considered as in Guenther et al. (1995):

$C_{T}=\frac{\exp \frac{C T 1(T-T s)}{R T s T}}{1+\exp \frac{C T 2(T-T M)}{R T s T}}$ for isoprene,

$C_{T}=\exp \left(\beta\left(T-T_{S}\right)\right)$ for all other compounds

$C_{L}=\frac{\alpha C L 1 Q}{\sqrt{1+\alpha^{2} Q^{2}}}$ considered for isoprene only

$\mathrm{T}$ is the leaf temperature $(\mathrm{K}), \mathrm{Q}$ is the incident flux of PAR $\left(\mu\right.$ mol.phot. $\left.\mathrm{m}^{-2} \mathrm{~s}^{-1}\right), \mathrm{T}_{s}$ is the leaf temperature at standard conditions $(=303 \mathrm{~K}), \mathrm{R}$ is the ideal 
Table 1. Biogenic emission factors in the ORCHIDEE model $(\mu \mathrm{gC} / \mathrm{gdm} / \mathrm{h})$.

\begin{tabular}{|c|c|c|c|c|c|c|c|c|}
\hline PFT & Isoprene & Monoterpenes & Methanol & Acetone & Acetaldehyde & Formaldehyde & Formic acid & Acetic Acid \\
\hline Tropical broadleaf evergreen tree & 24 & 0.8 & 0.6 & 0.29 & 0.1 & 0.07 & 0.01 & 0.002 \\
\hline Tropical broadleaf raingreen tree & 24 & 0.8 & 0.6 & 0.29 & 0.1 & 0.07 & 0.01 & 0.002 \\
\hline Temperate needleleaf evergreen tree & 8 & 2.4 & 1.8 & 0.87 & 0.3 & 0.2 & 0.03 & 0.006 \\
\hline Temperate broadleaf evegreen tree & 16 & 1.2 & 0.9 & 0.43 & 0.15 & 0.1 & 0.015 & 0.003 \\
\hline Temperate broadleaf summergreen tree & 45 & 0.8 & 0.6 & 0.29 & 0.1 & 0.07 & 0.01 & 0.002 \\
\hline Boreal needleleaf evergreen tree & 8 & 2.4 & 1.8 & 0.87 & 0.3 & 0.2 & 0.03 & 0.006 \\
\hline Boreal broadleaf summergreen tree & 8 & 2.4 & 1.8 & 0.87 & 0.3 & 0.2 & 0.03 & 0.006 \\
\hline Boreal needleleaf summergreen tree & 8 & 2.4 & 1.8 & 0.87 & 0.3 & 0.2 & 0.03 & 0.006 \\
\hline C3 grass & 16 & 0.8 & 0.6 & 0.29 & 0.1 & 0.07 & 0.01 & 0.002 \\
\hline $\mathrm{C} 4$ grass & 24 & 1.2 & 0.9 & 0.43 & 0.15 & 0.1 & 0.015 & 0.003 \\
\hline $\mathrm{C} 3$ agriculture & 5 & 0.2 & 2 & 0.07 & 0.025 & 0.017 & 0.0025 & 0.0005 \\
\hline $\mathrm{C} 4$ agriculture & 5 & 0.2 & 2 & 0.07 & 0.025 & 0.017 & 0.0025 & 0.0005 \\
\hline
\end{tabular}

gas constant $\left(=8.314 \mathrm{JK}^{-1} \mathrm{~mol}^{-1}\right) ; \mathrm{C}_{T 1}\left(=95000 \mathrm{Jmol}^{-1}\right)$, $\mathrm{C}_{T 2}\left(=230000 \mathrm{Jmol}^{-1}\right), \quad \mathrm{T}_{M} \quad(314 \mathrm{~K}), \quad \beta \quad\left(=0.09 \mathrm{~K}^{-1}\right), \quad \alpha$ $(=0.0027)$ and $\mathrm{C}_{L 1}(=1.066)$ are empirical coefficients.

Air temperature is often considered as an approximation of leaf temperature in biogenic emission models when a more detailed canopy energy balance is not available. The choice of the temperature used to calculate emissions is critical since temperature is a major factor governing biogenic emissions levels. Leaf temperature measurement is rather complex and published studies, analysing the difference between leaf and air temperature, are quite contrasted. Loreto et al. (1996) indicated that leaf temperature did not strictly follow changes in air temperature. Pier and McDuffie (1997) measured median leaf-to-air temperature differences of about $2^{\circ} \mathrm{C}$ at the canopy top and of $0.5^{\circ} \mathrm{C}$ or less within the canopy. Kirstine et al. (1998) found, on a pasture site, that the difference between leaf and air temperature, which tends to zero under freely evaporating conditions, increases under droughtstressed conditions by up to $5-10^{\circ} \mathrm{C}$. Martin et al. (1999) measured, over a two-month period, that the leaf temperature exceeded air temperature by more than $2^{\circ} \mathrm{C}$ on $10 \%$ of the daylight hours and the excess could go beyond $6^{\circ} \mathrm{C}$. Since the vegetation model ORCHIDEE does not calculate a separate leaf temperature, we use the surface temperature, which is the radiative budget temperature, including soil surface and canopy. However, the surface temperature can differ by up to $5^{\circ} \mathrm{C}$ or more from air temperature. In order to avoid a huge emissions overestimation, we thus impose that the temperature used in our biogenic emission model cannot differ by more than $2^{\circ} \mathrm{C}$ from air temperature, which is the most observed difference.

Several studies (MacDonald and Fall, 1993; Guenther et al., 2000) underline the impact of leaf age on the emission rate. They highlight that young leaves have a smaller emission capacity for isoprene, but a higher one for methanol, than mature leaves, and that old leaves have a strongly reduced emission yield. To account for the influence of leaf age, we assign a biogenic emission activity factor $\mathrm{L}_{a}$ (Eq. 1) for isoprene and methanol emissions, depending on the four leaf age classes given in ORCHIDEE. For methanol, we assume that mature and old leaf emission (leaf age classes 3 and 4) efficiency is half that of young leaves, and as the emission factors prescribed are typical of young leaves, we thus assign a leaf efficiency factor of 1 for leaf age classes 1 and 2 and of 0.5 for leaf age classes 3 and 4 (MacDonald and Fall, 1993). For isoprene, we consider that the emission factors given in Guenther et al. (1995) correspond to a medium-age vegetation emission capacity and assume that young and old leaves emit 3 times less then mature leaves. Therefore, we assign a leaf efficiency of 0.5 for leaf age classes 1 and 4 and of 1.5 for leaf age classes 2 and 3 (Guenther et al., 1999a).

\subsection{Simulations}

The model is run with a resolution of $1^{\circ}$ in longitude and $1^{\circ}$ in latitude and forced every $3 \mathrm{~h}$ by the ISLSCP-II (International Satellite Land-Surface Climatology Project, Initiative II Data Archive, NASA) satellite based climate archive (Hall et al., 2005). This forcing includes incident longwave and shortwave radiation at the surface, rainfall rate, ambient air temperature, surface pressure, near-surface wind speed, ambient air specific humidity and snowfall rate. These nearsurface meteorology data are based on atmospheric reanalyses from the NCEP/DOE (National Center for Environmental Predictions/Department of Energy) Reanalysis 2. For most of the fields, the reanalysis data has been hybridised with observational data or corrected for differences in elevation between the reanalysis model topography and the ISLSCP-II initial topography. The simulations are performed in static mode, which means that the vegetation distribution is prescribed using a global map. The variability of climate conditions and the atmospheric $\mathrm{CO}_{2}$ increase will thus not affect the vegetation distribution, but will impact the vegetation growth, and especially photosynthesis activity and carbon allocation to leaves. For our study, we use a present-day global map (Fig. 1) based on Loveland et al. (2000) and corrected for crops by Ramankutty and Folley 
Table 2. $\mathrm{CO}_{2}$ atmospheric levels and temperature conditions for the 1983-1995 interannual variability simulation.

\begin{tabular}{ccc}
\hline Year & $\begin{array}{c}\mathrm{CO}_{2} \text { mixing ratio }(\mathrm{ppm}) \text { and } \\
\text { increase from } 1983(\%)\end{array}$ & $\begin{array}{c}\text { Global mean } \\
\text { air temperature }\left({ }^{\circ} \mathrm{C}\right)\end{array}$ \\
\hline 1983 & 342.7 & 13.7 \\
1984 & $344.5(+0.52 \%)$ & 13.3 \\
1985 & $345.7(+0.87 \%)$ & 13.3 \\
1986 & $347.3(+1.34 \%)$ & 13.5 \\
1987 & $348.9(+1.81 \%)$ & 13.6 \\
1988 & $351.5(+2.57 \%)$ & 13.8 \\
1989 & $353.1(+3.03 \%)$ & 13.6 \\
1990 & $353.9(+3.27 \%)$ & 13.9 \\
1991 & $355.7(+3.79 \%)$ & 13.8 \\
1992 & $356.4(+3.99 \%)$ & 13.4 \\
1993 & $356.9(+4.14 \%)$ & 13.6 \\
1994 & $358.6(+4.63 \%)$ & 13.7 \\
1995 & $360.3(+5.13 \%)$ & 14.1 \\
& & 13.6 \\
\hline
\end{tabular}

(1999) and for anthropogenic grasses by Goldewijk (2001) (De Noblet-Ducoudré and Peterschmitt, unpublished work). Initial conditions are taken from a 10 -year equilibrated simulation based on 1983 climate and $\mathrm{CO}_{2}$ conditions. The interannual simulation, run for the 1983-1995 period, considers not only climate change but also annually varying $\mathrm{CO}_{2}$ atmospheric levels (Table 2): the $\mathrm{CO}_{2}$ mixing ratio increases from $342.7 \mathrm{ppmv}$ in 1983 up to $360.3 \mathrm{ppmv}$ in 1995, a 5\% increase over the 1983-1995 period (Keeling and Whorf 2005). The global and annual mean air temperature ranges from $13.3^{\circ} \mathrm{C}$ to $14.1^{\circ} \mathrm{C}$ (Table 2). The impact of key parameters, such as radiation extinction or temperature, on biogenic emissions is assessed running two sensitivity simulations, based on the 1983 climate and atmospheric $\mathrm{CO}_{2}$ conditions.

In order to evaluate the impact of human activities on ecosystems distribution and hence on biogenic emissions, we perform a second set of simulations: tropical deforestation and European afforestation. For the tropical deforestation simulation, PFTs 2 and 3 (tropical broadleaf evergreen and raingreen trees), located in large regions of South America, Africa and Indonesia, were replaced by 50\% tropical crops and 50\% tropical grasses (PFTs 11 and 13) while for the European afforestation simulation, we substituted crops (PFTs 12 and 13) with temperate broadleaf summergreen trees (PFT 6) in the regions between $37^{\circ} \mathrm{N}-70^{\circ} \mathrm{N}$ and $12^{\circ} \mathrm{W}-44^{\circ}$ E. For these simulations, we have only addressed the issue of human induced land cover change and ignored the potential impacts of climate and $\mathrm{CO}_{2}$ changes and of natural vegetation redistribution. We have then run one specific year using only the 1983 climate and $\mathrm{CO}_{2}$ conditions. Although these simulations do not include dynamic vegetation response to projected future climate and land use change, they do represent predicted regional land use tendencies and their impact on regional and global biogenic emissions.

\section{Global mean biogenic emissions for the 1983-1995 pe- riod}

\subsection{Comparison with other studies}

Calculated global mean emissions for the 1983-1995 period are summarized and compared to previous estimates in Table 3 . On a 13 years-mean basis, the global biogenic emission source calculated by our model totals $752 \mathrm{TgC} / \mathrm{yr}$ of which $460 \mathrm{TgC} / \mathrm{yr}$ are isoprene, $117 \mathrm{TgC} / \mathrm{yr}$ monoterpenes, $106 \mathrm{TgC} / \mathrm{yr}$ methanol, $42 \mathrm{TgC} / \mathrm{yr}$ acetone, $15 \mathrm{TgC} / \mathrm{yr}$ acetaldehyde, $10 \mathrm{TgC} / \mathrm{yr}$ formaldehyde, $1.5 \mathrm{TgC} / \mathrm{yr}$ formic acid and $0.3 \mathrm{TgC} / \mathrm{yr}$ acetic acid. Our results are within the range found in the literature. The slight underestimation when compared with Guenther et al. (1995) estimate of $506 \mathrm{TgC} / \mathrm{yr}$ for isoprene global emission results from our accounting of the leaf age influence. In a sensitivity study, we have indeed neglected this parameter and found a global isoprene emission of $506 \mathrm{TgC} / \mathrm{yr}$, identical to Guenther et al. (1995) and closer to the values reported by Wang and Shallcross (2000) and Levis et al. (2003). Monoterpenes emission calculated by ORCHIDEE is close to the $127 \mathrm{TgC} / \mathrm{yr}$ given by Guenther et al. (1995). Monoterpenes and other VOC emissions may also be dependent on the leaf age, although, to the best of our knowledge, this effect has only been studied for isoprene and methanol emissions. Global emissions calculated for aldehydes and acids are within the range given by Wiedinmyer et al. (2004). Biogenic emissions of acids total $1.8 \mathrm{TgC} / \mathrm{yr}$ from which formic acid emissions contribute to $1.5 \mathrm{TgC} / \mathrm{yr}$, 3 times less than the production of organics by ozonolysis reaction, estimated to $5 \mathrm{TgC} / \mathrm{yr}$ (Baboukas et al., 2000).

Our estimate of global isoprene emission is similar to the $454 \mathrm{TgC} / \mathrm{yr}$ reported by Naik et al. (2004). Naik et al. (2004) considered a potential vegetation map with no agricultural land, which should lead to higher emissions than ours. However, they assumed that grasses are not a major emitter of isoprene (emission factor of 0 ) while we use emissions factors of 16 and $24 \mu \mathrm{gC} / \mathrm{gdm} / \mathrm{h}$ for $\mathrm{C}_{3}$ and $\mathrm{C}_{4}$ grasses, respectively (Guenther et al., 1995), that results in an additional emission of $90 \mathrm{TgC} / \mathrm{yr}$ into the atmosphere.

Sanderson et al. (2003) calculated global emissions of $484 \mathrm{TgC} / \mathrm{yr}$ for isoprene, a little higher than our results, which can be explained again by the difference in emission factors. Based on a sensitivity analysis, we found that adopting the emission factors proposed by Sanderson et al. (2003) would lead to a global isoprene source about $485 \mathrm{TgC} / \mathrm{yr}$.

Tao and Jain (2005) estimated isoprene global biogenic emissions to $601 \mathrm{TgC} / \mathrm{yr}$, taking into account the leaf age influence. The emission factors were not assigned on a biome basis but depended on the grid cell considered and 
Table 3. Global mean biogenic emissions (TgC/yr) and contribution to total biogenic VOCs (\%) over the period $1983-1995$.

\begin{tabular}{|c|c|c|c|c|c|c|c|c|c|}
\hline $\mathrm{TgC} / \mathrm{yr}$ & Isoprene & Monoterpenes & Methanol & Acetone & Acetaldehyde & Formaldehyde & Formic acid & Acetic acid & TOTAL \\
\hline This study & $\begin{array}{c}460 \\
(61 \%)\end{array}$ & $\begin{array}{c}117 \\
(15 \%)\end{array}$ & $\begin{array}{c}106 \\
(14 \%)\end{array}$ & $\begin{array}{c}42 \\
(6 \%)\end{array}$ & $\begin{array}{c}15 \\
(2 \%)\end{array}$ & $\begin{array}{c}10 \\
(1.5 \%)\end{array}$ & $\begin{array}{c}1.5 \\
(0.2 \%)\end{array}$ & $\begin{array}{c}0.3 \\
(0.05 \%)\end{array}$ & 752 \\
\hline $\begin{array}{l}\text { Galbally and Kirstine } \\
(2002)\end{array}$ & & & 37.5 & & & & & & \\
\hline Guenther et al. (1995) & 503 & 127 & & & & & & & 1150 \\
\hline Horowitz et al. (2003) & & & 107 & & & & & & \\
\hline Levis et al. (2003) & 507 & 33 & & & & & & & 692 \\
\hline $\begin{array}{l}\text { Naik et al. (2004) (poten- } \\
\text { tial vegetation) }\end{array}$ & 454 & 72 & & & & & & & \\
\hline Sanderson et al. (2003) & 484 & & & & & & & & \\
\hline Tie et al. (2003) & & & 108 & & & & & & \\
\hline $\begin{array}{l}\text { Wang and Shallcross } \\
(2000)\end{array}$ & 530 & & & & & & & & \\
\hline Wiedinmyer et al. (2004) & & & $50-250$ & $10-50$ & $10-50$ & $2-10$ & $0.4-2$ & $0.4-2$ & \\
\hline
\end{tabular}

thus showed a strong variability throughout the world, which is not the case in our study.

If the results calculated with our model compare well with other estimates on a global basis, they do emphasize the sensitivity of computed biogenic emissions to the chosen emission factors. Indeed, an emission factor allocation based only on PFTs may not be sufficient to take into account the large emission factor variability from one ecosystem to another and to provide a realistic regional distribution of biogenic compounds, which can be of great importance, especially for atmospheric chemistry studies. Serça et al. (2001) investigated isoprene emission in a forest-site of the Republic of Congo, as part of the EXPRESSO program, and found that of the 28 species from the mixed forest, only 3 were high isoprene emitters (emission rate over $16 \mu \mathrm{gC} / \mathrm{g} / \mathrm{h}$ ) while in the monospecific forest, 2 species had high emission rates (45 and $62 \mu \mathrm{gC} / \mathrm{g} / \mathrm{h}$ ), for the same conditions of temperature and PAR. Growth environmental conditions such as long-term variation in light, temperature and water stress presumably regulate emissions capacity as observed for isoprene (Harley et al., 1999; Hanson and Sharkey, 2001a; Pétron et al., 2001) and monoterpenes (Staudt et al., 2003). VOC biogenic emissions calculation should then integrate those parameters and a more complex emission factors prescription, depending not only on PFT but also on the geographical location should then be used, as proposed by Guenther et al. (2006) in the MEGAN model.

Galbally and Kirstine (2002) estimated methanol emissions by flowering plants to $100 \mathrm{Tg}$ of methanol per year (37.5 TgC/yr), based on plant structure and metabolic properties. This work, which leads to significantly lower emissions compared to ours, uses a completely different approach based on a plant physiology model. Horowitz et al. (2003) estimated biogenic methanol emissions of $108 \mathrm{TgC} / \mathrm{yr}$, based on the emission ratio to isoprene found by Guenther et al. (2000) for North America. Tie et al. (2003) studied the impact of biogenic methanol on tropospheric oxidants as-

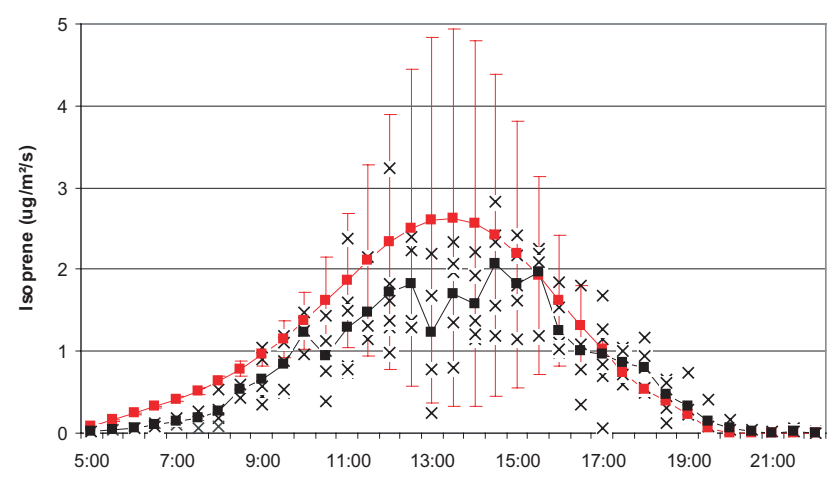

Fig. 3. Comparison of the ORCHIDEE results with measurements of the ECHO campaign (Spirig et al., 2005) for isoprene $\left(\mu \mathrm{g} / \mathrm{m}^{2} / \mathrm{s}\right)$. Monthly mean ORCHIDEE isoprene emissions for July (red squares) and variance (red bars) are compared to the mean diurnal cycle (black squares) measured during the ECHO campaign, and to the fluxes reported day-by-day (black crosses).

suming a global surface methanol source of $117 \mathrm{TgC} / \mathrm{yr}$, of which $92 \%$ is due to biogenic sources, that is $108 \mathrm{TgC} / \mathrm{yr}$, which is very similar to our results.

Comparison of the ORCHIDEE monthly mean emissions fluxes over the 1983-1995 with a limited compilation of measurements is given in Table 4 and show that the results of our model are broadly within the range of selected measurements. In the Fig. 3, the diurnal isoprene emissions cycle calculated by our model is compared to measurements of the ECHO campaign (Spirig et al., 2005), which took place in North-West Germany in July 2003, and we can see that in this case, the diurnal variation of isoprene fluxes is quite well captured by our model. It is of course difficult to evaluate a global model based only on a few comparisons with measurements, and a more detailed validation is required. Nevertheless, the examples shown in Table 4 and Fig. 3 underline that our model is generally consistent with the measurements. 

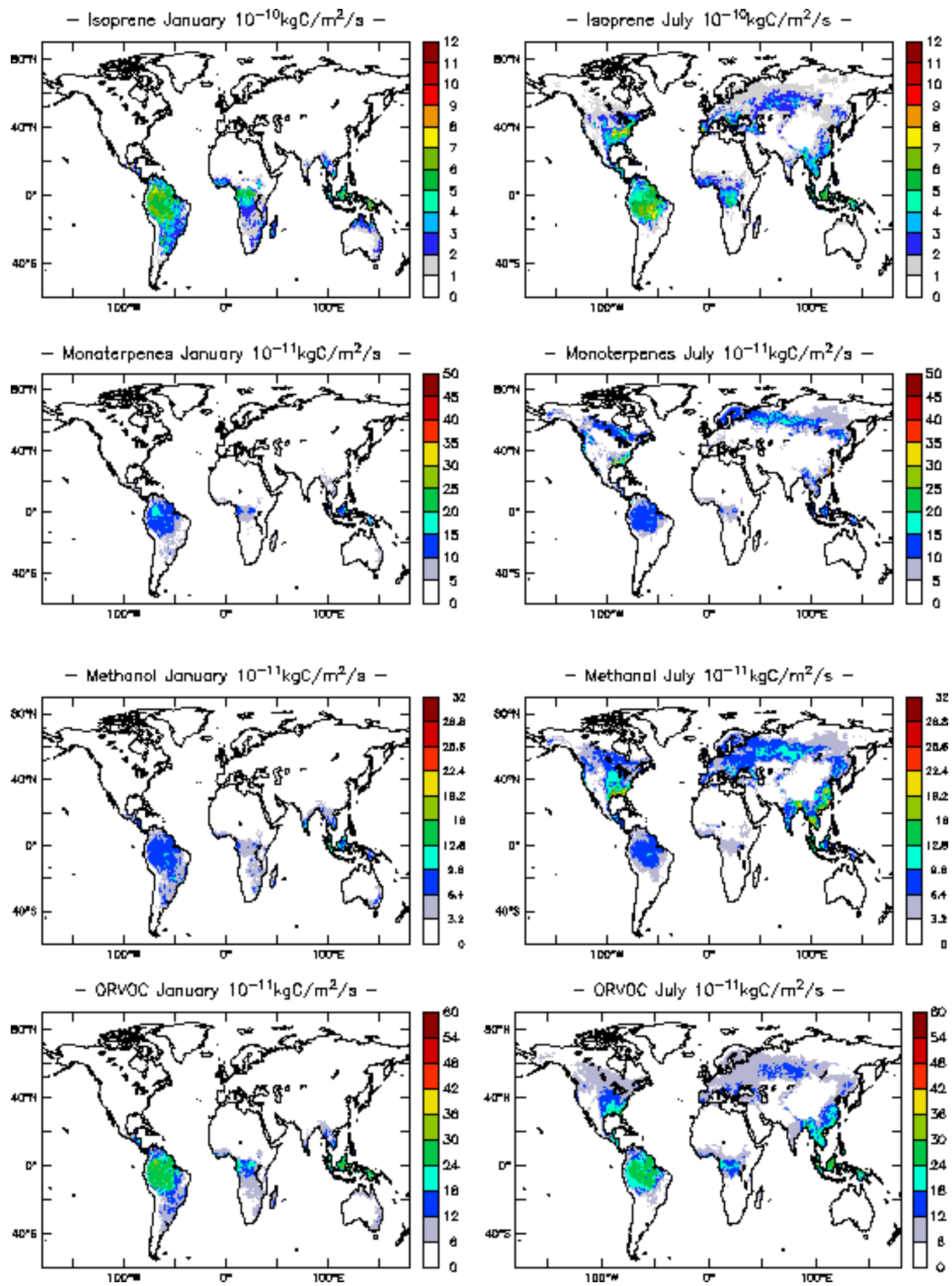

Fig. 4. Global mean biogenic emissions over the $1983-1995$ period in $\mathrm{kgC} / \mathrm{m}^{2} / \mathrm{s}$ in January (left column) and July (right column) for isoprene, monoterpenes, methanol and ORVOC. 
Table 4. Comparison of the ORCHIDEE 1983-1995 mean biogenic emissions with on-site measurements $\left(\mathrm{mgC}^{2} \mathrm{~m}^{2} / \mathrm{h}\right)$.

\begin{tabular}{|c|c|c|c|c|c|}
\hline Sources & Location & Compound & Period & Measurement & This study \\
\hline \multirow[b]{2}{*}{ Pattey et al. (1999) } & \multirow[b]{2}{*}{ Canada } & \multirow[b]{2}{*}{ Isoprene } & July & $1.10-4.58$ & 0.43 \\
\hline & & & September & $0.4-1.67$ & 0.13 \\
\hline Westberg et al. (2001) & USA & Isoprene & August & $\begin{array}{l}9-10.5 \text { (warm period) } \\
0.9-1.8 \text { (cool period) }\end{array}$ & \multirow[t]{2}{*}{1.8} \\
\hline Apel et al. (2002) & USA & Isoprene & Summer & $9(\max )$ & \\
\hline \multirow{4}{*}{ Karl et al. (2003) } & \multirow{4}{*}{ USA } & Isoprene & Summer & $6.7(\max )$ & 2.2 \\
\hline & & \multirow{2}{*}{ Methanol } & \multirow[t]{2}{*}{ Spring } & 0.4 (mean) & \multirow[t]{2}{*}{0.11} \\
\hline & & & & $0.7(\max )$ & \\
\hline & & Acetone & Fall & 0.3 (mean) & 0.1 \\
\hline Greenberg et al. (1999) & Congo & Isoprene & November & $0.6-1.3$ & 1.9 \\
\hline \multirow[t]{2}{*}{ Rinne et al. (2002) } & \multirow[t]{2}{*}{ Brazil } & \multirow[t]{2}{*}{ Isoprene } & July & 1.8 & 2.2 \\
\hline & & & May & 0.32 & 0.25 \\
\hline \multirow[t]{2}{*}{ Ciccioli et al. (2003) } & \multirow[t]{2}{*}{ Italy } & \multirow[t]{2}{*}{ Monoterpenes } & July & 2.09 & 0.5 \\
\hline & & & November & 0.16 & 0.14 \\
\hline Rinne et al. (1999) & Finland & Monoterpenes & Summer & $0.5-0.6(\max )$ & 0.3 \\
\hline Spanke et al. (2001) & Finland & Monoterpenes & Spring and Summer & $0.063-0.3(\max )$ & $0.2-0.3$ \\
\hline
\end{tabular}

\subsection{Attribution of global emissions to PFTs and VOC com- ponents}

Three major biogenic compounds are emitted: isoprene, which contribute to more than $61 \%$ to the global annual biogenic emissions, monoterpenes (15\%) and methanol (14\%) (Table 3). However, even if other compounds such as acetone $(6 \%)$, acetaldehyde or formaldehyde ( $2 \%$ and $1.5 \%$ ), formic $(0.2 \%)$ and acetic $(0.05 \%)$ acids are emitted in smaller individual quantities, these other species total a significant amount of reactive compounds emitted to the atmosphere, of almost $70 \mathrm{TgC} / \mathrm{yr}$.

Figure 4 shows the geographical distribution of calculated emissions for isoprene, monoterpenes, methanol and ORVOC (defined as other reactive VOCs with lifetime smaller than 1 day, and calculated with a constant emission factor of $1.5 \mu \mathrm{gC} / \mathrm{gdm} / \mathrm{h}$ for every PFTs, Guenther et al., 1995). In January, significant emissions of $2-8 \times 10^{-10} \mathrm{kgC} / \mathrm{m}^{2} / \mathrm{s}$ for isoprene and $5-20 \times 10^{-11} \mathrm{kgC} / \mathrm{m}^{2} / \mathrm{s}$ for monoterpenes are calculated in the southern hemisphere and tropical regions. Isoprene is primarily emitted in tropical regions, because tropical vegetation (PFTs 2 and 3 ) are characterized by both high leaf area index up to $7-8 \mathrm{~m}^{2} / \mathrm{m}^{2}$ (Fig. 2) and strong emissions factors (Table 1). High isoprene emissions occur all year in these regions. In July, high isoprene emissions by $3-10 \times 10^{-10} \mathrm{kgC} / \mathrm{m}^{2} / \mathrm{s}$ are also calculated locally in the east coast of the US and in southern Spain due to a high density of temperate broadleaf summergreen trees (PFT 6). Monoterpenes emission levels are also significant in tropical regions, but do not extend as much as isoprene emissions to the south of the Amazon region. In July, high monoterpenes emissions of $10-20 \times 10^{-11} \mathrm{kgC} / \mathrm{m}^{2} / \mathrm{s}$ are found in Siberia and Canada, whereas tropical regions contribute much less to the global monoterpenes emission. The biogenic emissions of other VOCs such as acetone, acids and aldehydes have the same pattern because their emissions factors and emission parameterization are similar to monoterpenes. Methanol emissions are particularly high in tropical regions such as India or the southern Asia, due to a high density of crops, a strong methanol emitter, in those regions. In July, methanol emissions range from 6 to over $20 \times 10^{-11} \mathrm{kgC} / \mathrm{m}^{2} / \mathrm{s}$ in Indonesia.

Table 5 shows the contribution of various PFTs and regions to the global biogenic emissions on a 1983-1995 mean basis. The contribution of tropical vegetation (PFTs 2 and 3 ) to the global emissions are $61 \%$ for isoprene, $53 \%$ for monoterpenes but only 32\% for methanol. Crops (PFTs 12 and 13) are significant methanol emitters, contributing to $44 \%$ of global methanol emissions, but are much less important for isoprene and other VOCs $(6-6.5 \%$ of global emissions). Tropical regions are a major contributor to global annual biogenic emissions: $83 \%$ of isoprene, $69 \%$ of monoterpenes and $66 \%$ of methanol global annual emissions originate from tropical regions $\left(30^{\circ} \mathrm{S}-30^{\circ} \mathrm{N}\right)$. In our study, grasses (PFTs 10 and 11) are a significant source of isoprene contributing to $20 \%$ of the global yearly emission. This result is in contrast with other studies (Levis et al., 2003; Naik et al., 2004), which assume that grasses do not emit isoprene at a significant level. Even if the maximum leaf area index for grasses is only $2.5 \mathrm{~m}^{2} / \mathrm{m}^{2}$, we consider quite high isoprene 
Table 5. Contribution of PFTs and various regions to global biogenic emissions in TgC/yr (and \%) on a 1983-1995 mean basis. Tropical regions are defined between $+/-30^{\circ}$ and $0^{\circ}$, higher latitude regions are defined between $+/-30^{\circ}$ and $+/-90^{\circ}$.

\begin{tabular}{lcccc}
\hline PFT & Isoprene & Monoterpenes & Methanol & Acetone \\
\hline Tropical broadleaf evergreen tree & $258(56 \%)$ & $58(50 \%)$ & $31(30 \%)$ & $21(50 \%)$ \\
Tropical broadleaf raingreen tree & $23(5 \%)$ & $3.5(3 \%)$ & $2(2 \%)$ & $1.5(3 \%)$ \\
Temperate needleleaf evergreen tree & $7(2 \%)$ & $13(11 \%)$ & $7(7 \%)$ & $5(11 \%)$ \\
Temperate broadleaf evergreen tree & $12(3 \%)$ & $4.5(4 \%)$ & $2.5(2 \%)$ & $2(4 \%)$ \\
Temperate broadleaf summergreen tree & $32(7 \%)$ & $3(2 \%)$ & $1.5(1 \%)$ & $1(2 \%)$ \\
Boreal needleleaf evergreen tree & $5(1 \%)$ & $11(9 \%)$ & $6(5 \%)$ & $4(9 \%)$ \\
Boreal broadleaf summergreen tree & $1.5(0.33 \%)$ & $2(2 \%)$ & $1(1 \%)$ & $0.8(2 \%)$ \\
Boreal needleleaf summergreen tree & $1(0.2 \%)$ & $1(0.9 \%)$ & $1(0.6 \%)$ & $0.4(0.9 \%)$ \\
C3 Grass & $44(10 \%)$ & $8(7 \%)$ & $4.5(4 \%)$ & $3(7 \%)$ \\
C4 Grass & $46(10 \%)$ & $7(6 \%)$ & $4(4 \%)$ & $3(6 \%)$ \\
C3 Agriculture & $15(3 \%)$ & $3(3 \%)$ & $22(22 \%)$ & $1(3 \%)$ \\
C4 Agriculture & $16(3.5 \%)$ & $3(3 \%)$ & $23(22 \%)$ & $1(3 \%)$ \\
& & & & \\
Tropics & $381(83 \%)$ & $82(69 \%)$ & $70(66 \%)$ & $30(70 \%)$ \\
Tropical South & $213(46 \%)$ & $45(38 \%)$ & $33(31 \%)$ & $16(38 \%)$ \\
Tropical North & $168(37 \%)$ & $37(31 \%)$ & $37(35 \%)$ & $13.5(31 \%)$ \\
Higher South & $8(2 \%)$ & $2(2 \%)$ & $3(2 \%)$ & $0.8(2 \%)$ \\
Higher North & $71(15 \%)$ & $34(29 \%)$ & $33(31 \%)$ & $12(29 \%)$ \\
Europe & $14(3 \%)$ & $5(4 \%)$ & $7(6 \%)$ & $2(4 \%)$ \\
& & & & \\
Global & 460 & 117 & 106 & 42 \\
\hline
\end{tabular}

emission factors, as given in Guenther et al. (1995) for hot and cool grass/shrub, and the spatial coverage and density of grasses is often very high. It is thus a critical point to know if grasses can be considered as an isoprene emitter or not since a very different regional isoprene emissions distribution would arise. Several studies emphasized the low isoprene emission level of grasses but the number of species of grass that emit isoprene is highly uncertain (Holzinger et al., 2002; Wiedinmyer et al., 2004). Moreover, high isoprene emission capacities have been measured for shrubs (Guenther et al., 1999b), which are included in PFTs 10 and 11. Grasses are of less importance for other VOCs emissions, for which their contribution is between 8 and $13 \%$.

\subsection{Sensitivity tests to parameters choices}

Additional simulations were conducted for the year 1983 to assess the sensitivity of biogenic emissions to key parameters such as temperature, leaf age or radiation extinction within the canopy (Eq. 1). We estimated that the radiation extinction considered for isoprene emissions leads to the halving of isoprene emission, decreasing from $983 \mathrm{TgC} / \mathrm{yr}$ without radiation extinction to $478 \mathrm{TgC} / \mathrm{yr}$. Accounting for the leaf age influence leads to a decrease in global emissions of $10 \%$ for isoprene and $27 \%$ for methanol. Increasing the surface temperature (used as a surrogate of leaf temperature) in the biogenic emissions model globally by $1^{\circ} \mathrm{C}$ leads to an increase in the global emission of $11 \%$ for isoprene and $9 \%$ for other compounds $(478 \mathrm{TgC} / \mathrm{yr}$ to $529 \mathrm{TgC} / \mathrm{yr}$ for isoprene, $119 \mathrm{TgC} / \mathrm{yr}$ to $129 \mathrm{TgC} / \mathrm{yr}$ for monoterpenes, $106 \mathrm{TgC} / \mathrm{yr}$ to $116 \mathrm{TgC} / \mathrm{yr}$ for methanol and $43 \mathrm{TgC} / \mathrm{yr}$ to $47 \mathrm{TgC} / \mathrm{yr}$ for acetone) resulting in a substantial additional total emission of VOCs to the atmosphere of $78 \mathrm{TgC} / \mathrm{yr}$. Considering the difficulty in estimating leaf temperature and the canopy energy balance highlights the large uncertainty in calculated biogenic emissions. The next step for biogenic emission model improvement would be to calculate the leaf temperature for sunlit and shaded leaves, as suggested by measurements given by Harley et al. (1997).

\section{Interannual variability of biogenic emissions over the period 1983-1995}

In this section, the impact of the variability in climate conditions and of increasing atmospheric $\mathrm{CO}_{2}$ concentrations on biogenic emissions is investigated over the period 19831995. As shown in Table 6, the total global emission of all biogenic compounds ranges from $717 \mathrm{TgC} / \mathrm{yr}$ in 1986 to $778 \mathrm{TgC} / \mathrm{yr}$ in 1995 , that is a $8.5 \%$ increase between both extreme values, and has a variability of $+/-16 \mathrm{TgC} / \mathrm{yr}$ over the 1983-1995 period. In order to asses the impact of atmospheric $\mathrm{CO}_{2}$ mixing ratio increase on biogenic emissions, we performed a second 1983-1995 simulation considering the $1983 \mathrm{CO}_{2}$ atmospheric level (342.7 ppmv) for the whole period (Table 6). In 1995, the emissions difference between the 
Table 6. Interannual variability of biogenic emissions over the 1983-1995 period ( $\mathrm{TgC} / \mathrm{yr})$.

\begin{tabular}{|c|c|c|c|c|c|c|c|c|c|c|c|}
\hline & \multicolumn{2}{|c|}{ Isoprene } & \multirow[t]{2}{*}{ Monoterpenes } & \multirow[t]{2}{*}{ Methanol } & \multirow[t]{2}{*}{ Acetone } & \multirow[t]{2}{*}{ Acetaldehyde } & \multirow[t]{2}{*}{ Formaldehyde } & \multirow{2}{*}{$\begin{array}{c}\text { Formic } \\
\text { acid }\end{array}$} & \multirow{2}{*}{$\begin{array}{c}\text { Acetic } \\
\text { acid }\end{array}$} & \multicolumn{2}{|c|}{ TOTAL } \\
\hline & $\begin{array}{l}1983 \\
\mathrm{CO}_{2}\end{array}$ & $\begin{array}{c}\text { Increasing } \\
\mathrm{CO}_{2}\end{array}$ & & & & & & & & $\begin{array}{l}1983 \\
\mathrm{CO}_{2}\end{array}$ & $\begin{array}{c}\text { Increasing } \\
\mathrm{CO}_{2}\end{array}$ \\
\hline 1983 & 478 & 478 & 118 & 106 & 43 & 14.8 & 10.2 & 1.48 & 0.295 & 772 & 772 \\
\hline 1984 & 459 & 459 & 116 & 105 & 42 & 14.5 & 10.0 & 1.45 & 0.291 & 747 & 748 \\
\hline 1985 & 454 & 454 & 116 & 105 & 42 & 14.6 & 10.0 & 1.46 & 0.291 & 743 & 743 \\
\hline 1986 & 435 & 436 & 113 & 102 & 41 & 14.1 & 9.7 & 1.41 & 0.283 & 714 & 717 \\
\hline 1987 & 465 & 467 & 118 & 106 & 42 & 14.7 & 10.1 & 1.47 & 0.293 & 754 & 759 \\
\hline 1988 & 454 & 457 & 117 & 106 & 42 & 14.6 & 10.0 & 1.46 & 0.292 & 742 & 748 \\
\hline 1989 & 451 & 453 & 117 & 106 & 42 & 14.6 & 10.0 & 1.46 & 0.292 & 738 & 744 \\
\hline 1990 & 465 & 468 & 121 & 109 & 44 & 15.1 & 10.4 & 1.51 & 0.30 & 762 & 769 \\
\hline 1991 & 459 & 463 & 120 & 107 & 43 & 14.9 & 10.3 & 1.49 & 0.299 & 752 & 760 \\
\hline 1992 & 445 & 449 & 115 & 103 & 41 & 14.4 & 9.9 & 1.44 & 0.287 & 725 & 734 \\
\hline 1993 & 451 & 456 & 117 & 106 & 42 & 14.6 & 10.0 & 1.46 & 0.291 & 736 & 747 \\
\hline 1994 & 458 & 462 & 119 & 107 & 43 & 14.8 & 10.2 & 1.48 & 0.297 & 747 & 758 \\
\hline 1995 & 472 & 476 & 122 & 109 & 44 & 15.2 & 10.4 & 1.52 & 0.304 & 768 & 778 \\
\hline
\end{tabular}

"constant $\mathrm{CO}_{2}$ " simulation and the "increasing $\mathrm{CO}_{2}$ " simulation reaches $4 \mathrm{TgC} / \mathrm{yr}$ for isoprene and $10 \mathrm{TgC} / \mathrm{yr}$ for the total VOC, which corresponds to $0.8 \%$ and $1.3 \%$ difference, respectively, linked to an increase in foliar biomass under increasing atmospheric $\mathrm{CO}_{2}$ conditions.

An important control on climate conditions in tropical regions is the occurrence of El Niño and La Niña events, which lead to major warming and cooling cycles in the eastern and central Pacific. The Southern Oscillation Index (SOI), defined as the pressure difference between Tahiti and Darwin, provides the intensity of El Niño and La Niña episodes. As shown in Table 6, biogenic emissions are generally higher during El Niño years (1983, 1987, 1990-1991 and 19941995), and lower during La Niña years (1984-1985, 19881989). A similar finding was obtained by Naik et al. (2004) over the period 1971-1990. However there is an exception for the 1992-1993 weak El Niño event for which global biogenic emissions are lower than average. For those two years, the El Niño effect on the temperature increase in the western part of South America is very small (with a maximum increase of $0.4^{\circ} \mathrm{C}$ in northern part of South America compared to $1983-1995$ mean temperature of $26-28^{\circ} \mathrm{C}$ in this region), and does not impact significantly on biogenic emissions levels, whereas a temperature decrease can be noted southward of Brazil and in Central Africa, leading to a decrease in biogenic emissions. The comparison between the SOI and the calculated monthly global isoprene emissions anomalies (Fig. 5) indicates a negative correlation. The correlation coefficient ( $r$ ) between the SOI and monthly global biogenic emissions anomalies, calculated for the period 1983-1995, is -0.28 for isoprene, -0.14 for monoterpenes and -0.01 for methanol. These values are in qualitative agreement with Naik et al. (2004) but of smaller absolute correlation $(-0.54$ for isoprene and -0.24 for monoterpenes for 1971-1990, in Naik et al., 2004). The correlation coefficients obtained
Comparison between the SOI and biogenic emissions anomaly

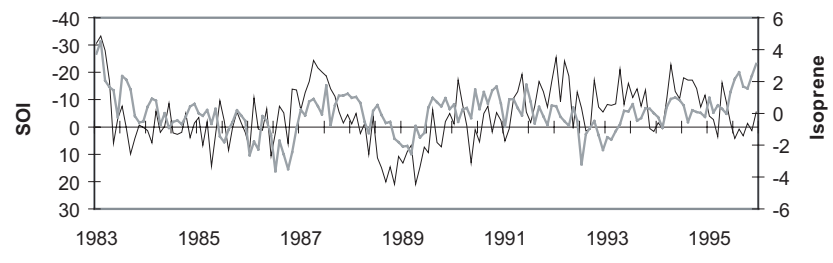

Fig. 5. Comparison between the Southern Oscillation Index SOI (black line) and the simulated anomalies of global monthly biogenic isoprene emissions (grey line, $\mathrm{TgC} /$ month) for the 1983-1995 period.

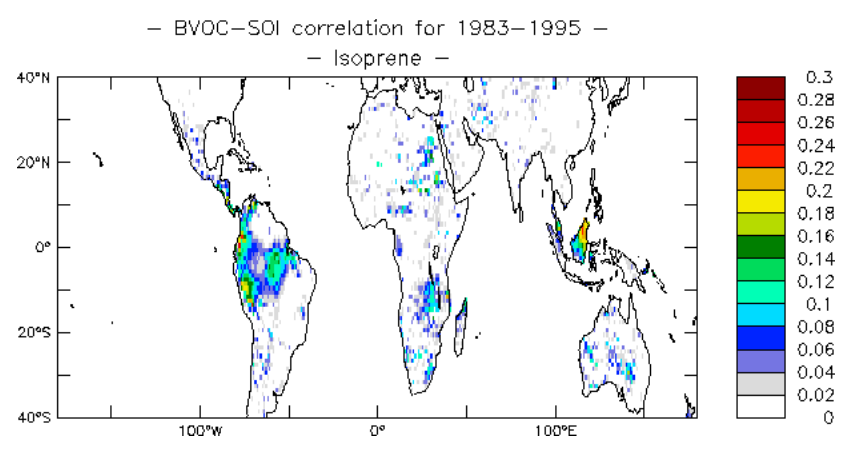

Fig. 6. Square correlation coefficient $\left(r^{2}\right)$ between the Southern Oscillation Index and biogenic isoprene emissions for the 19831995 period.

are rather small but it is however interesting to note that the correlation between biogenic emissions and SOI is somewhat higher in tropical regions compared to other regions, as shown in Fig. 6 for isoprene.

As indicated by Fig. 6, the variability in biogenic emissions over the 13 years of the simulation varies from one 

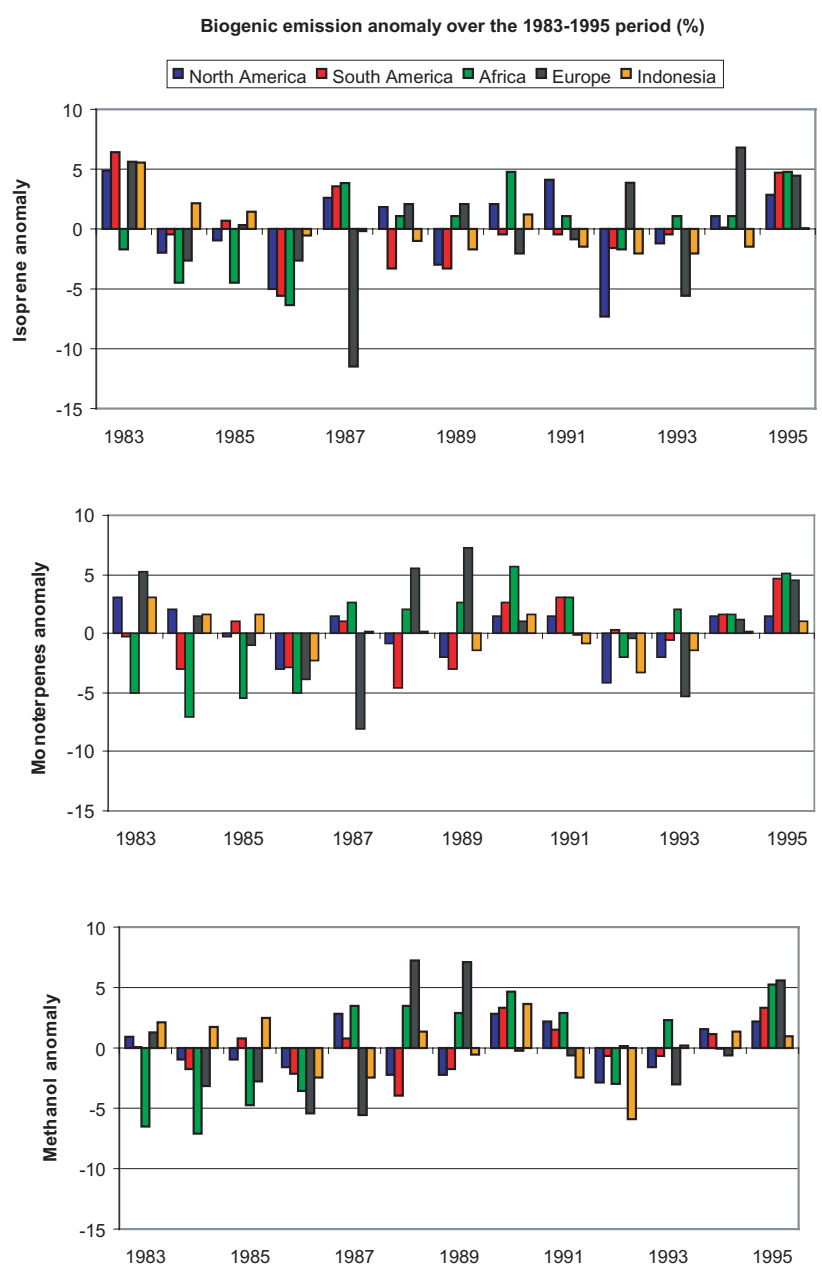

Fig. 7. Variability of annual biogenic emissions anomaly based on 1983-1995 mean emissions calculated for North America, South America, Africa, Europe and Indonesia for isoprene (upper panel), monoterpenes (middle panel) and methanol (lower panel).

region to another. To further illustrate this feature, Fig. 7 shows the annual emission anomaly in \%, compared to 19831995 mean emissions, calculated for isoprene, monoterpenes and methanol for 5 regions: North America $(150 \mathrm{~W}-52 \mathrm{~W}$, $12 \mathrm{~N}-70 \mathrm{~N}$ ), South America ( $85 \mathrm{~W}-34 \mathrm{~W}, 60 \mathrm{~S}-15 \mathrm{~N})$, Africa $(18 \mathrm{~W}-51 \mathrm{E}, 35 \mathrm{~S}-37 \mathrm{~N})$, Europe $(10 \mathrm{~W}-50 \mathrm{E}, 35 \mathrm{~N}-72 \mathrm{~N})$ and Indonesia $(60 \mathrm{E}-160 \mathrm{E}, 11 \mathrm{~S}-40 \mathrm{~N})$. Biogenic emissions variability is strongly affected by the evolution of environmental conditions such as radiation, temperature or leaf area index. In Europe, in relation to a strong air temperature variability over the period 1983-1995, the emission anomaly has the largest variability from $-11.5 \%$ to $+6.8 \%$ for isoprene, from $-8.1 \%$ to $+7.2 \%$ for monoterpenes and from $-5.6 \%$ to $+7.2 \%$ for methanol. In 1987 , biogenic emissions have a strong negative anomaly in Europe, where annual mean air temperature differs the most from 1983-1995 mean temperature compared to other regions studied, especially for
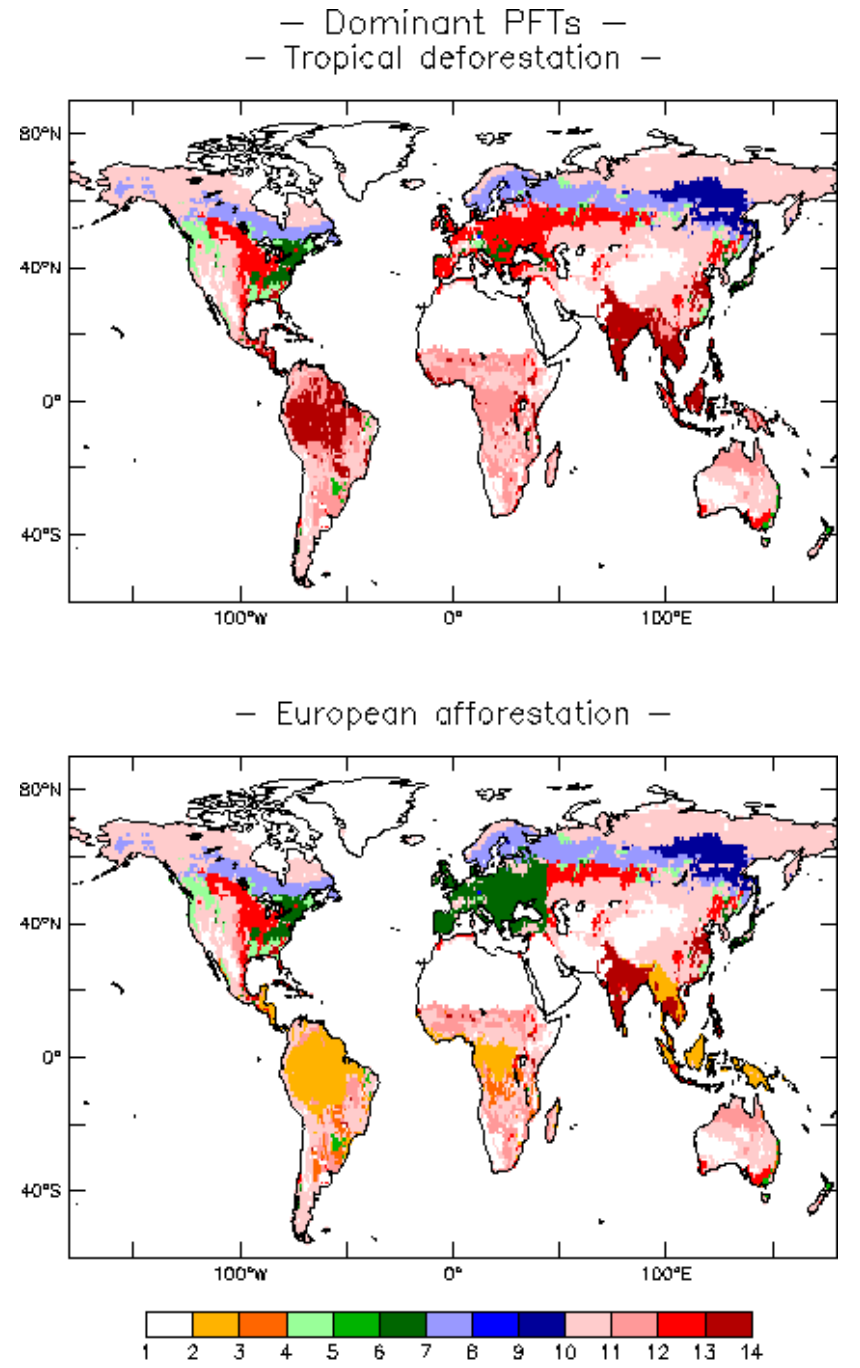

Fig. 8. PFTs distribution considered for the Tropical deforestation (upper panel) and European afforestation (lower panel) scenarios.

isoprene $(-11.5 \%)$ and monoterpenes $(-8.1 \%)$. The amplitude of the isoprene emission anomaly is about $10 \%$ for North and South America and Africa, but smaller for Indonesia $(7.5 \%)$. Variation in the emission anomaly is lowest in Indonesia $(-3.3 \%$ to $+3 \%)$ and North America $(-4.2 \%$ to $+3.1 \%)$ for monoterpenes and in North $(-2.9 \%$ to $2.8 \%)$ and South $(-3.9 \%$ to $+3.3 \%)$ America for methanol.

\section{Impacts of tropical deforestation and European af- forestation on global biogenic emissions}

\subsection{Tropical deforestation}

Figure 9 illustrates the change in total annual mean leaf area index between the tropical deforestation scenario and the 1983 control run (1983 simulation with non-modified present vegetation map). In the tropical regions with low 
Table 7. Global biogenic emissions (TgC/yr) and changes (\%) for the tropical deforestation simulation and European afforestation simulation compared to the control run (nc: no change).

\begin{tabular}{lccccccc}
\hline \multirow{2}{*}{ TgC/yr (\%) } & \multicolumn{3}{c}{ 1983 Control Run } & \multicolumn{2}{c}{ Tropical deforestation } & \multicolumn{2}{c}{ European afforestation } \\
& Global & Tropics & Europe & Global & Tropics & Global & Europe \\
\hline Isoprene & 478 & 396 & 15 & $339(-29 \%)$ & $257(-35 \%)$ & $497(+4 \%)$ & $33(+126 \%)$ \\
Monoterpenes & 118 & 81 & 5 & $84(-29 \%)$ & $48(-41 \%)$ & $118(-0.1 \%)$ & $6(+13 \%)$ \\
Methanol & 106 & 70 & 7 & $130(+22 \%)$ & $93(+33 \%)$ & $102(-3.5 \%)$ & $3(-51 \%)$ \\
Acetone & 43 & 29 & 2 & $30(-29 \%)$ & $17(-42 \%)$ & $43(-0.2 \%)$ & $2(+10 \%)$ \\
Acetaldehyde & 15 & 10 & 0.64 & $10(-29 \%)$ & $6(-42 \%)$ & $15(\mathrm{nc})$ & $0.7(+16 \%)$ \\
Formaldehyde & 10 & 7 & 0.44 & $7(-30 \%)$ & $4(-44 \%)$ & $10(\mathrm{nc})$ & $0.5(+14 \%)$ \\
Formic acid & 1.5 & 1 & 0.06 & $1(-29 \%)$ & $0.6(-44 \%)$ & $1.48(\mathrm{nc})$ & $0.07(+14 \%)$ \\
Acetic acid & 0.29 & 0.20 & 0.013 & $0.21(-27 \%)$ & $0.12(-40 \%)$ & $0.29(\mathrm{nc})$ & $0.015(+15 \%)$ \\
& & & & & & & \\
TOTAL & 772 & 595 & 30 & $602(-22 \%)$ & $426(-20 \%)$ & $787(+2 \%)$ & $46(+54 \%)$ \\
\hline
\end{tabular}

precipitation, such as the southern part of Brazil, the LAI is quite small in the control run $\left(1-3 \mathrm{~m}^{2} / \mathrm{m}^{2}\right)$. Deforestation leads to a small increase in LAI in this region between 1 and $1.5 \mathrm{~m}^{2} / \mathrm{m}^{2}$. In significant parts of Amazonia, Central Africa and Indonesia, a large decrease in LAI in the range $2-4.5 \mathrm{~m}^{2} / \mathrm{m}^{2}$ is modelled.

Tropical deforestation has a major impact on biogenic emissions, as shown in Table 7. On a global basis, methanol emissions increase by $22 \%$, in relation to crops coverage expansion, whereas isoprene and other VOC emissions decrease by $27-30 \%$. If we consider tropical regions only, a $33 \%$ increase in methanol emissions occurs and a $35-44 \%$ decrease is predicted for isoprene and other VOCs. The isoprene emission decrease calculated for East Asia reaches $26 \%$, which is closed to the $30 \%$ decrease calculated by Steiner et al. (2002). Moreover, as illustrated in Fig. 9 by the zonal mean difference of biogenic emissions between the tropical deforestation simulation and the control run, the seasonality of emissions is also affected by the tropical deforestation. The decrease in isoprene zonal mean emissions, governed by a reduction in both LAI and emission factors under tropical deforestation conditions, is significant all year long $\left(-0.5 \times 10^{-10}\right.$ to $\left.-2 \times 10^{-10} \mathrm{kgC} / \mathrm{m}^{2} / \mathrm{s}\right)$ and peaks in March north of the Equator and in September south of the Equator $\left(-2 \times 10^{-10}\right.$ to $\left.-3.5 \times 10^{-10} \mathrm{kgC} / \mathrm{m}^{2} / \mathrm{s}\right)$. Methanol zonal mean emissions increase by $0.5-4 \times 10^{-11} \mathrm{kgC} / \mathrm{m}^{2} / \mathrm{s}$ throughout the year, and by $4-5 \times 10^{-11} \mathrm{kgC} / \mathrm{m}^{2} / \mathrm{s}$ from January to September between $0^{\circ}$ and $10^{\circ} \mathrm{S}$. A decrease in zonal mean methanol emissions is also modelled north of the equator in March, and south of the equator in September $(-0.5$ to $\left.-2.5 \times 10^{-11} \mathrm{kgC} / \mathrm{m}^{2} / \mathrm{s}\right)$. This reduction in methanol emissions is due to the large decrease in LAI in these regions, and occurs despite the significantly larger methanol emission factors of crops compared to tropical trees (Table 1). These results illustrate the importance of tropical regions as a major and very sensitive biogenic emissions source, under pressure from rapid and strong land use change.

\subsection{European afforestation}

Under the European afforestation scenario, the total annual mean LAI tends to decrease by $1 \mathrm{~m}^{2} / \mathrm{m}^{2}$ over large regions of Europe, and up to $2 \mathrm{~m}^{2} / \mathrm{m}^{2}$ in Great-Britain, where the highest LAI decrease occurs. LAI increases locally by up to $2.5 \mathrm{~m}^{2} / \mathrm{m}^{2}$ in the centre of Europe, northward of the Black Sea (Fig. 10). This result, which can seem surprising, is linked to the fact that we turn perennial crops into a summergreen vegetation, both characterized by a maximum LAI of $5 \mathrm{~m}^{2} / \mathrm{m}^{2}$. We know that perennial crops are not realistic and this is being changed in ORCHIDEE (Gervois et al., 2004). Nevertheless, this bias in the representation of crops only marginally affects the results discussed here.

Globally, emissions are not significantly affected by European afforestation: a $4 \%$ increase is calculated for isoprene and a $3.5 \%$ decrease for methanol, and less than $0.2 \%$ for other VOCs is computed. However, at the European scale, the impact is very significant, with a $51 \%$ decrease in methanol emissions, an increase of $126 \%$ for isoprene and $10-15 \%$ for other VOCs, leading to an increase in total biogenic emissions in Europe of 54\%. The very large increase in the isoprene emission factor (multiplied by 9 compared to crops) leads to a large overall increase in biogenic emissions, despite the small decrease in LAI. The combined effect of total LAI and emission factor reduction leads to a large decrease in methanol emissions, lasting through the year since methanol crops emissions also occur in winter in the control run while there is no emission by PFT 6 (summergreen trees) during winter. The change in zonal mean emissions, given in Fig. 10 , shows a $0.5 \times 10^{-10}$ to $4.5 \times 10^{-10} \mathrm{kgC} / \mathrm{m}^{2} / \mathrm{s}$ increase in zonal mean isoprene emissions from April to November. Zonal mean methanol emissions decrease by $0.5 \times 10^{-11}$ $1.5 \times 10^{-11} \mathrm{kgC} / \mathrm{m}^{2} / \mathrm{s}$, between January and March and after October, and by $1.5 \times 10^{-11}-5 \times 10^{-11} \mathrm{kgC} / \mathrm{m}^{2} / \mathrm{s}$, during spring and summer. For both isoprene and methanol, the maximum change in zonal mean emissions occurs in July 
- Tropical deforestation -
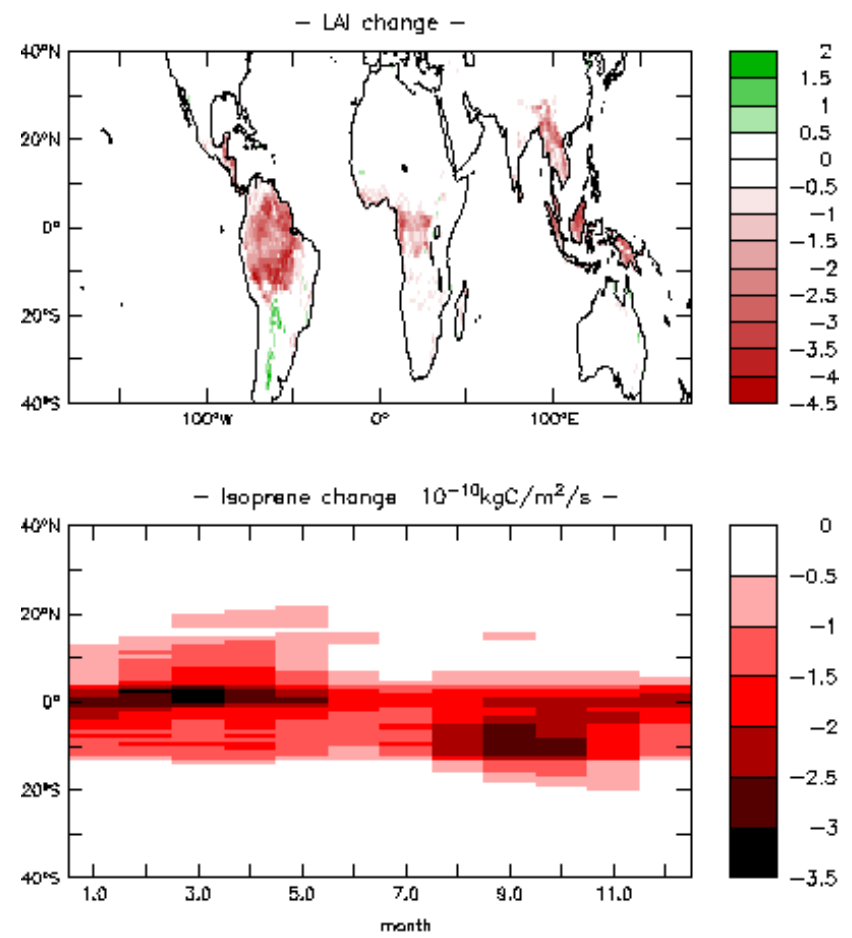

- Methanol change $10^{-11} \mathrm{kgC} / \mathrm{m}^{2} / 5-$

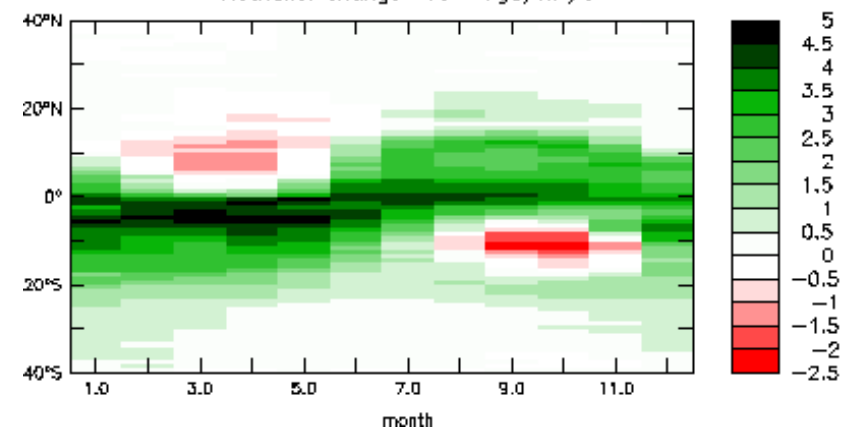

Fig. 9. Impact of a tropical deforestation scenario on total annual mean LAI $\left(\mathrm{m}^{2} / \mathrm{m}^{2}\right)$ (upper panel), zonal mean isoprene (middle panel) and methanol (lower panel) emissions compared to the 1983 control run.

between $42^{\circ} \mathrm{N}$ and $52^{\circ} \mathrm{N}$. Even though global biogenic emissions are not significantly affected by European afforestation, its impact on regional emissions is very large and could strongly influence tropospheric chemistry mechanisms both within and outside Europe.

The vegetation distribution change considered in our study is only intended to be a sensitivity experiment and probably overestimates the future changes. Nevertheless, the results obtained in the tropical deforestation and European reforestation simulations underline the strong impact of vegetation distribution alteration on VOC biogenic emissions as well as the high dependency of emission levels to the evolution of land management.
- European afforestation -

- LAl change -
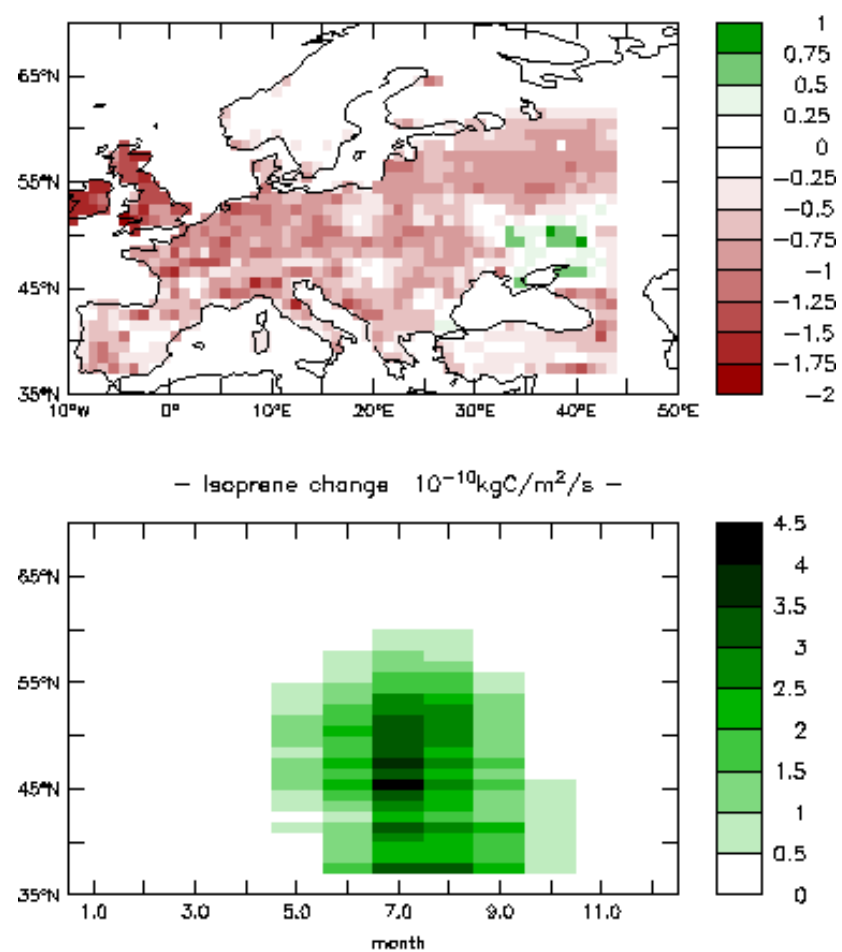

- Methanal change $10^{-11} \mathrm{kgC} / \mathrm{m}^{2} / \mathrm{s}-$

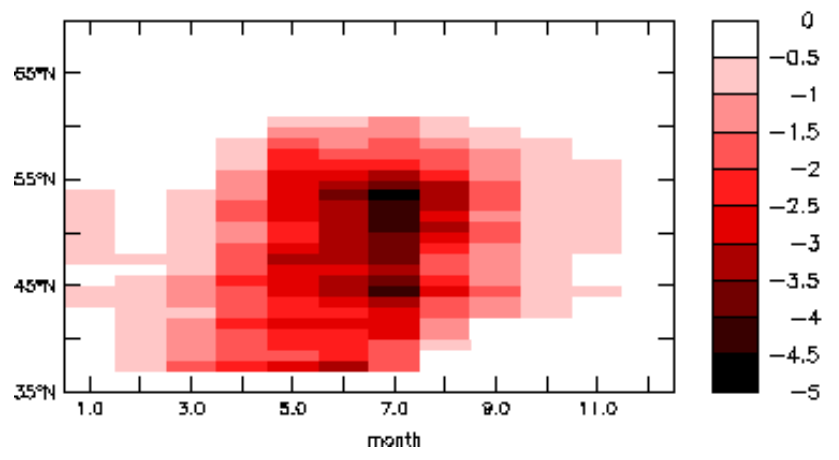

Fig. 10. Impact of a European afforestation scenario on total annual mean LAI $\left(\mathrm{m}^{2} / \mathrm{m}^{2}\right)$ (upper panel), zonal mean isoprene (middle panel) and methanol (lower panel) emissions compared to the 1983 control run.

\section{Conclusion}

A biogenic emission scheme has been integrated in the global vegetation model ORCHIDEE in order to calculate biogenic emissions of isoprene, monoterpenes, methanol, acetone, acetaldehyde, formaldehyde, as well as formic and acetic acids at the global scale. In order to study the impact of climate and land use changes on biogenic emissions, several simulations are performed. Global mean emissions of $460 \mathrm{TgC} / \mathrm{yr}$ for isoprene, $117 \mathrm{TgC} / \mathrm{yr}$ for monoterpenes, $106 \mathrm{TgC} / \mathrm{yr}$ for methanol and $42 \mathrm{TgC} / \mathrm{yr}$ for acetone are calculated over the 
period 1983-1995. Tropical regions are identified as the primary source of global biogenic VOCs, contributing to $83 \%$ of isoprene, $69 \%$ of monoterpenes and $66 \%$ of methanol global annual emissions. The interannual simulation predicts a substantial variability in biogenic emissions over the 19831995 period. The total global and annual emissions of the summed VOCs range from $718 \mathrm{TgC} / \mathrm{yr}$ (1986) to $778 \mathrm{TgC} / \mathrm{yr}$ (1995), i.e. an $8.4 \%$ variability over $1983-1995$. The variability in emissions is markedly different from one region to another. Among the regions studied, biogenic emissions variation compared to 1983-1995 mean emissions was found to be the highest in Europe and the smallest in Indonesia (isoprene and monoterpenes) and North America (methanol).

Two scenarios of land use change, tropical deforestation and European afforestation, have been considered to examine the sensitivity of biogenic emissions to the vegetation distribution alteration. On the global scale, our calculations indicate that the tropical deforestation leads to a methanol emission increase by $22 \%$, whereas isoprene and other VOCs emissions decrease by $27-30 \%$. If we consider tropical regions only, a $33 \%$ increase is calculated for methanol emissions, and a $35-44 \%$ decrease is estimated for isoprene and other VOCs. Global emissions are not significantly affected by the European afforestation, but at the european scale, the impact is much more important, with a $51 \%$ decrease for methanol emissions and an increase of $126 \%$ for isoprene and $10-15 \%$ for other VOCs, leading to an increase in the total biogenic emissions in Europe of 54\%.

Our results are generally consistent with previous studies. It should be noted that our study also takes into account features such as the leaf age for isoprene and methanol emissions. Based on a sensitivity test, we estimated that accounting for the leaf age influence leads to a decrease in global emissions of $10 \%$ for isoprene and $27 \%$ for methanol. Future biogenic emission studies need to consider if grasses can be considered as a significant isoprene emitter or not as this could greatly affect regional isoprene emissions distribution. Indeed, we calculate that grasses contribute to nearly $20 \%$ of the isoprene global and annual emission whereas recent studies such as Levis et al. (2003) and Naik et al. (2004) assume that the grass isoprene emission factor is negligible. Depending on this choice, our emission estimates for land-use change scenarios, such as European afforestation and Tropical deforestation, could be significantly different.

Air temperature above the canopy is used to calculate biogenic emissions when a more accurate canopy energy balance, estimating leaf temperature is not available. Pier and McDuffie (1997) observed, comparing measurements and model emissions, that calculating biogenic emissions based on air temperature leads to a slight underestimation of high emission rates. Hanson and Sharkey (2001b) pointed out that biogenic emission models should be adjusted to account for variation in response to temperature and light levels during vegetation growth, which could be done simply by altering the emission capacity (other coefficients used in light and temperature emissions dependencies were not found to be sensitive to environmental growth conditions). Increasing globally the leaf temperature used in the biogenic emissions model by $1^{\circ} \mathrm{C}$ leads to an increase in the global emission of $11 \%$ for isoprene and $9 \%$ for other compounds $(478 \mathrm{TgC} / \mathrm{yr}$ to $529 \mathrm{TgC} / \mathrm{yr}$ for isoprene, $119 \mathrm{TgC} / \mathrm{yr}$ to $129 \mathrm{TgC} / \mathrm{yr}$ for monoterpenes, $106 \mathrm{TgC} / \mathrm{yr}$ to $116 \mathrm{TgC} / \mathrm{yr}$ for methanol and $43 \mathrm{TgC} / \mathrm{yr}$ to $47 \mathrm{TgC} / \mathrm{yr}$ for acetone) resulting in a substantial additional emission of VOCs to the atmosphere of $78 \mathrm{TgC} / \mathrm{yr}$. The difficulty to estimate the leaf temperature and the canopy energy balance appears as a major uncertainty in calculating biogenic emissions. A next step for biogenic emissions models improvement would be to calculate the leaf temperature for sunlit and shaded leaves, as suggested by the measurements of Harley et al. (1997).

The distribution, as well as the diversity, of vegetation throughout the world is under pressure from both direct anthropogenic changes, such as deforestation and agriculture expansion, driven by population growth, and indirect changes, also affected partly by human activities, including atmospheric $\mathrm{CO}_{2}$ and climate evolution. Alcamo et al. (1996) suggested that in the next 50 years, land-cover conversion may occur predominantly in the tropical and subtropical regions, in response to projections of demographic growth and economic activity. The consequences of such changes not only on biogenic emissions but also on the tropospheric gas phase and particulate chemistry could be significant. The use of dynamic global vegetation models, for future scenarios, and more generally for climate and land use change studies, is an essential next step. Nevertheless, important points, such as the pattern and dependency of emissions on environmental conditions for compounds other than isoprene and monoterpenes, and the response of foliar density and biogenic emission factors to $\mathrm{CO}_{2}$ and climate change, are still under debate. Rosenstiel et al. (2003) showed that under increased atmospheric $\mathrm{CO}_{2}$ level from $430 \mathrm{ppmv}$ to 800 and $1200 \mathrm{ppmv}$, the isoprene production was reduced by $21 \%$ and $41 \%$ while above-ground biomass accumulation was enhanced by $60 \%$ and $82 \%$. We can reasonably consider that considering this influence in our study would not change significantly the estimates calculated over the 1983-1995 period, characterized by a 5\% increase of the atmospheric $\mathrm{CO}_{2}$ but could however be subsequent on longer time-scales. The influences of those various parameters could affect emissions levels significantly, and more information is needed to reduce the estimates uncertainty and improve our understanding of biosphere-atmosphere interactions.

Acknowledgements. We thank J.-Y. Peterschmitt for his help in the preparation of the global vegetation maps. Useful comments and discussions on this work by P. Friedlingstein, D. Serça, G. Krinner, A. Guenther and S. Gervois are gratefully acknowledged. Computer time has been provided by the C.C.R.T under project p24. This work was partly funded by the European projects RETRO (EVK2-CT-2002-00170) and ENSEMBLES (GOCE- 
CT-2003-505539). G. Folberth acknowledges support provided by the Canadian Centre for Climate Modelling and Analysis, Meteorological Service of Canada.

Edited by: U. Lohmann

\section{References}

Alcamo, J., Kreileman, G. J. J., Bollen, J. C., vandenBorn, G. J., Gerlagh, R., Krol, M. S., Toet, A. M. C., and deVries, H. J. M.: Baseline scenarios of global environmental change, Global Environmental Change-Human and Policy Dimensions, 6(4), 261303, 1996.

Andreae, M. O. and Crutzen, P. J.: Atmospheric aerosols: biogeochemical sources and role in atmospheric chemistry, Science, 276, 1052-1058, 1997.

Apel, E. C., Riemer, D. D., Hills, A., Baugh, W., Orlando, J., Faloona, I., Tan, D., Brune, W., Lamb, B., Westberg, H., Carroll, M. A., Thornberry, T., and Geron, C. D.: Measurement and interpretation of isoprene fluxes and isoprene, methacrolein, and methyl vinyl ketone mixing ratios at the PROPHET site during the 1998 Intensive, J. Geophys. Res., 107, D3, doi:10.1029/2000JD000225, 2002.

Baboukas, E. D., Kanakidou, M., and Mihalopoulos, N.: Carboxylic acids in gas and particulate phase above the Atlantic Ocean, J. Geophys. Res.-Atmos., 105(D11), 14459-14471, 2000.

Barket, D. J., Grossenbacher, J. W., Hurst, J. M., Shepson, P. B., Olszyna, K., Thornberry, T., Carroll, M. A., Roberts, J., Stroud, C., Bottenheim, J., and Biesenthal, T.: A study of the NOx dependence of isoprene oxidation, J. Geophys. Res., 109, D11, doi:10.1029/2003JD003965, 2004.

Ciais, P., Reichstein, M., Viovy, N., Granier, A., Ogee, J., Allard, V., Aubinet, M., Buchmann, N., Bernhofer, C., Carrara, A., Chevallier, F., De Noblet, N., Friend, A. D., Friedlingstein, P., Grunwald, T., Heinesch, B., Keronen, P., Knohl, A., Krinner, G., Loustau, D., Manca, G., Matteucci, G., Miglietta, F., Ourcival, J. M., Papale, D., Pilegaard, K., Rambal, S., Seufert, G., Soussana, J. F., Sanz, M. J., Schulze, E. D., Vesala, T., and Valentini, R.: Europe-wide reduction in primary productivity caused by the heat and drought in 2003, Nature, 437(7058), 529-533, 2005.

Ciccioli, P., Brancaleoni, E., Frattoni, M., Marta, S., Brachetti, A., Vitullo, M., Tirone, G., and Valentini, R.: Relaxed eddy accumulation, a new technique for measuring emission and deposition fluxes of volatile organic compounds by capillary gas chromatography and mass spectrometry, J. Chromatogr. A, 985(1-2), 283-296, 2003.

Claeys, M., Graham, B., Vas, G., Wang, W., Vermeylen, R., Pashynska, V., Cafmeyer, J., Guyon, P., Andreae, M. O., Artaxo, P., and Maenhaut, W.: Formation of secondary organic aerosols through photooxidation of isoprene, Science, 303(5661), 11731176, 2004.

De Rosnay, P. and Polcher, J.: Modeling root water uptake in a complex land surface scheme coupled to a GCM, Hydrol. Earth Syst. Sci., 2, 239-256, 1998, mboxhttp://www.hydrol-earth-systsci.net/2/239/1998/.

Ducoudré, N., Laval, K., and Perrier, A.: SECHIBA, a new set of parameterizations of the hydrologic exchanges at the land- atmosphere interface within the LMD atmospheric general circulation model, J. Climate, 6, 248-273, 1993.

Fehsenfeld, F., Calvert, J., Fall, R., Goldan, P., Guenther, A. B., Hewitt, C. N., Lamb, B., Liu, S., Trainer, M., Westberg, H., and Zimmerman, P.: Emissions of volatile organic compounds from vegetation and the implications for atmospheric chemistry, Global Biogeochem. Cycles, 6(4), 389-430, 1992.

Galbally, I. E. and Kirstine, W.: The production of methanol by flowering plants and the global cycle of methanol, J. Atmos. Chem., 43, 195-229, 2002.

Ganzeveld, L. and Lelieveld, J.: Impact of Amazonian deforestation on atmospheric chemistry, Geophys. Res. Lett., 31, 6, doi:10.1029/2003GL019205, 2004.

Gervois, S., De Noblet-Ducoudré, N., Viovy, N., Ciais, P., Brisson, N., Seguin, B., and Perrier, A.: Including croplands in a global biosphere model: methodology and evaluation at specific sites, Earth Interactions, 8, Paper 16, 1-25, 2004.

Goldewijk, K. K.: Estimating global land use change over the past 300 years: The HYDE Database, Global Biogeochem. Cycles, 15(2), 417-433, 2001.

Greenberg, J. P., Guenther, A., Madronich, S., Baugh, W., Ginoux, P., Druilhet, A., Delmas, R., and Delon, C.: Biogenic volatile organic compound emissions in central Africa during the Experiment for the Regional Sources and Sinks of Oxidants (EXPRESSO) biomass burning season, J. Geophys. Res., 104(D23), 30 659-30 671, 1999.

Griffin, R. J., Cocker, D. R., Seinfeld, J. H., and Dabdub, D.: Estimate of global atmospheric organic aerosol from oxidation of biogenic hydrocarbons, Geophys. Res. Lett., 26(17), 2721-2724, 1999.

Guenther, A., Hewitt, C. N., Erickson, D., Fall, R., Geron, C., Graedel, T., Harley, P., Klinger, L., Lerdau, M., McKay, W. A., Pierce, T., Scholes, B., Steinbrecher, R., Tallamraju, R., Taylor, J., and Zimmerman, P.: A global model of natural volatile organic compound emissions, J. Geophys. Res., 100(D5), 88738892, 1995.

Guenther, A., Baugh, B., Brasseur, G., Greenberg, J., Harley, P., Klinger, L., Serça, D., and Vierling, L.: Isoprene emission estimates and uncertainties for the Central African EXPRESSO study domain, J. Geophys. Res., 104(D23), $30625-$ $30639,1999 a$.

Guenther, A., Archer, S., Harley, P., Helmig, D., Klinger, L., Vierling, L., Wildermuth, M., Zimmerman, P., and Zitzer, S.: Biogenic hydrocarbon emissions and landcover/climate change in a subtropical savanna, Phys. Chem. Earth, 24(6), 659-667, 1999b.

Guenther, A., Geron, C., Pierce, T., Lamb, B., Harley, P., and Fall, R.: Natural emissions of non-methane volatile organic compounds, carbon monoxide, and oxides of nitrogen from North America, Atmos. Environ., 34, 2205-2230, 2000.

Guenther, A., Karl, T., Harley, P., Wiedinmyer, C., Palmer, P. I., and Geron, C.: Estimates of global terrestrial isoprene emissions using MEGAN (Model of Emissions of Gases and Aerosols from Nature), Atmos. Chem. Phys. Discuss., 6, 107-173, 2006, mboxhttp://www.atmos-chem-phys-discuss.net/6/107/2006/.

Hall, F. G., Collatz, G., Los, S., Brown de Colstoun, E., and Landis, D. (Eds.): ISLSCP Initiative II, 2005.

Hanson, D. T. and Sharkey, T. D.: Effect of growth conditions on isoprene emission and other thermotolerance-enhancing compounds, Plant Cell and Environment, 24(9), 929-936, 2001a. 
Hanson, D. T. and Sharkey, T. D.: Rate of acclimation of the capacity for isoprene emission in response to light and temperature, Plant Cell and Environment, 24(9), 937-946, $2001 \mathrm{~b}$.

Harley, P., Guenther, A., and Zimmerman, P.: Environmental controls over isoprene emission in deciduous oak canopies, Tree Physiology, 17, 705-714, 1997.

Harley, P. C., Monson, R. K., and Lerdau, M. T.: Ecological and evolutionary aspects of isoprene emission from plants, Oecologia, 118, 109-123, 1999.

Holzinger, R., Sanhueza, E., von Kuhlmann, R., Kleiss, B., Donoso, L., and Crutzen, P. J.: Diurnal cycles and seasonal variation of isoprene and its oxidation products in the tropical savanna atmosphere, Global Biogeochem. Cycles, 16, 4, doi:10.1029/2001GB001421, 2002.

Horowitz, L. W., Walters, S., Mauzerall, D. L., Emmons, L. K., Rasch, P. J., Granier, C., Tie, X. X., Lamarque, J. F., Schultz, M. G., Tyndall, G. S., Orlando, J. J., and Brasseur, G. P.: A global simulation of tropospheric ozone and related tracers: Description and evaluation of MOZART, version 2, J. Geophys. Res., 108, D24, doi:10.1029/2002JD002853, 2003.

Janson, R. and De Serves, C.: Acetone and monoterpene emissions from the boreal forest in northern Europe, Atmos. Environ., 35, 4629-4637, 2001.

Kanakidou, M., Tsigaridis, K., Dentener, F., and Crutzen, P. J.: Human-activity-enhanced formation of organic aerosols by biogenic hydrocarbon oxidation, J. Geophys. Res., 105(D7), 92439254, 2000.

Karl, T., Guenther, A., Spirig, C., Hansel, A., and Fall, R.: Seasonal variation of biogenic VOC emissions above a mixed hardwood forest in northern Michigan, Geophys. Res. Lett., 30, 23, 2003.

Kavouras, I. G., Mihalopoulos, N., and Stephanou, E. G.: Formation and gas/particle partitioning of monoterpenes photooxidation products over forests, Geophys. Res. Lett., 26(1), 5558, 1999.

Keeling, C. D. and Whorf., T. P.: Atmospheric CO2 records from sites in the SIO air sampling network. In Trends: A Compendium of Data on Global Change. Carbon Dioxide Information Analysis Center, Oak Ridge National Laboratory, U.S. Department of Energy, Oak Ridge, Tenn., USA, 2005.

Kesselmeier, J. and Staudt, M.: Biogenic volatile organic compounds (VOC): An overview on emission, physiology, and ecology, J. Atmos. Chem., 33(1), 23-88, 1999.

Kirstine, W., Galbally, I., Ye, Y., and Hooper, M.: Emissions of volatile organic compounds (primarily oxigenated species) from pasture, J. Geophys. Res., 103(D9), 10 605-10 619, 1998.

Krinner, G., Viovy, N., De Noblet, N., Ogée, J., Polcher, J., Friedlingstein, P., Ciais, P., Sitch, S., and Prentice, I. C.: A dynamic global vegetation model for studies of the coupled atmosphere-biosphere system, Global Biogeochem. Cycles, 19, 1, doi:10.1029/2003GB002199, 2005.

Lathiere, J., Hauglustaine, D. A., De Noblet-Ducoudre, N., Krinner, G., and Folberth, G. A.: Past and future changes in biogenic volatile organic compound emissions simulated with a global dynamic vegetation model, Geophys. Res. Lett., 32, 20, doi:10.1029/2005GL024164, 2005.

Levis, S., Wiedinmyer, C., Bonan, G. B., and Guenther, A.: Simulating biogenic volatile organic compound emissions in the Community Climate System Model, J. Geophys. Res., 108, D21, doi:10.1029/2002JD003203, 2003.
Limbeck, A., Kulmala, M., and Puxbaum, H.: Secondary organic aerosol formation in the atmosphere via heterogeneous reaction of gaseous isoprene on acidic particles, Geophys. Res. Lett., 30, 19, doi:10.1029/2003GL017738, 2003.

Loreto, F., Ciccioli, P., Cecinato, A., Brancaleoni, E., Frattoni, M., and Tricoli, D.: Influence of environmental factors and air composition on the emission of alpha-pinene from Quercus ilex leaves, Plant Physiology, 110(1), 267-275, 1996.

Loveland, T. R., Reed, B. C., Brown, J. F., Ohlen, D. O., Zhu, Z., Yang, L., and Merchant, J. W.: Development of a global land cover characteristics database and IGBP DISCover from $1 \mathrm{~km}$ AVHRR data, Intern. J. Rem. Sens., 21(6-7), 1303-1330, 2000.

MacDonald, R. and Fall, R.: Detection of substantial emissions of methanol from plants to the atmosphere, Atmos. Environ., 27A(11), 1709-1713, 1993.

Martin, T. A., Hinckley, T. M., Meinzer, F. C., and Sprugel, D. G.: Boundary layer conductance, leaf temperature and transpiration of Abies amabilis branches, Tree Physiology, 19(7), 435-443, 1999.

Naik, V., Delire, C., and Wuebbles, D. J.: Sensitivity of global biogenic isoprenoid emissions to climate variability and atmospheric CO2, J. Geophys. Res., 109, D6, doi:10.1029/2003JD004236, 2004.

Pattey, E., Desjardins, R. L., Westberg, H., Lamb, B., and Zhu, T.: Measurement of isoprene emissions over a black spruce stand using a tower-based relaxed eddy accumulation system, J. Appl. Meteorol., 38, 870-877, 1999.

Pétron, G., Harley, P., Greenberg, J., and Guenther, A.: Seasonal temperature variations influence isoprene emission, Geophys. Res. Lett., 28(9), 1707-1710, 2001.

Pier, P. A. and McDuffie, C.: Seasonal isoprene emission rates and model comparisons using whole-tree emissions from white oak, J. Geophys. Res., 102(D20), 23 963-23 971, 1997.

Pun, B. K., Wu, S. Y., and Seigneur, C.: Contribution of biogenic emissions to the formation of ozone and particulate matter in the eastern united states, Environ. Sci. Technol., 36(16), 3586-3596, 2002.

Ramankutty, N. and Foley, J. A.: Estimating historical changes in global land cover: Croplands from 1700 to 1992, Global Biogeochem. Cycles, 13(4), 997-1027, 1999.

Rinne, H. J. I., Guenther, A. B., Greenberg, J. P., and Harley, P. C.: Isoprene and monoterpene fluxes measured above Amazonian rainforest and their dependence on light and temperature, Atmos. Environ., 36(14), 2421-2426, 2002.

Rinne, J., Hakola, H., and Laurila, T.: BVOC emissions at the canopy scale: micrometeorological flux measurements, Biphorep - Biogenic VOC emissions and photochemistry in the boreal regions of Europe, edited by: Laurila, T. and Lindfors, V., Luxembourg, 73-81, 1999.

Rosenstiel, T. N., Potosnak, M. J., Griffins, K. L., Fall, R., and Monson, R. K.: Increased CO2 uncouples growth from isoprene emission in an agriforest ecosystem, Nature, 421, 256-259, 2003.

Sanderson, M. G., Jones, C. D., Collins, W. J., Johnson, C. E., and Derwent, R. G.: Effect of climate change on isoprene emissions and surface ozone levels, Geophys. Res. Lett., 30, 18, doi:10.1029/2003GL017642, 2003.

Schade, G. W. and Goldstein, A. H.: Fluxes of oxygenated volatile organic compounds from a ponderosa pine plantation, J. Geophys. Res., 106(D3), 3111-3123, 2001. 
Serça, D., Guenther, A., Klinger, L., Vierling, L., Harley, P., Druilhet, A., Greenberg, J., Baker, B., Baugh, W., Bouka-Biona, C., and Loema-Ndembi, L.: EXPRESSO flux measurements at upland and lowland Congo tropical forest site, Tellus, 53B, 220234, 2001.

Sitch, S., Smith, B., Prentice, I. C., Arneth, A., Bondeau, A., Cramer, W., Kaplan, J. O., Levis, S., Lucht, W., Sykes, M. T., Thonicke, K., and Venevsky, S.: Evaluation of ecosystem dynamics, plant geography and terrestrial carbon cycling in the LPJ dynamic global vegetation model, Global Change Biol., 9(2), $161-185,2003$

Sotiropoulou, R. E. P., Tagaris, E., Pilinis, C., Andronopoulos, S., Sfetsos, A., and Bartzis, J. G.: The BOND project: Biogenic aerosols and air quality in Athens and Marseille greater areas, $\mathrm{J}$. Geophys. Res., 109, D5, doi:10.1029/2003JD003955, 2004.

Spanke, J., Rannik, U., Renate, F., Nigge, W., and Hoffmann, T.: Emission fluxes and atmospheric degradation of monoterpenes above a boreal forest: field measurements and modelling, Tellus, 53B, 406-442, 2001.

Spirig, C., Neftel, A., Ammann, C., Dommen, J., Grabmer, W., Thielmann, A., Schaub, A., Beauchamp, J., Wisthaler, A., and Hansel, A.: Eddy covariance flux measurements of biogenic VOCs during ECHO 2003 using proton transfer reaction mass spectrometry, Atmos. Chem. Phys., 5, 465-481, 2005, mboxhttp://www.atmos-chem-phys.net/5/465/2005/.

Stanturf, J. A. and Madsen, P.: Restoration concepts for temperate and boreal forests of North America and Western Europe, Plant Biosystems, 136(2), 143-158, 2002.

Staudt, M., Joffre, R., and Rambal, S.: How growth conditions affect the capacity of Quercus ilex leaves to emit monoterpenes, New Phytologist, 158(1), 61-73, 2003.

Steiner, A., Luo, C., Huang, Y., and Chameides, W. L.: Past and present-day biogenic volatile organic compound emissions in East Asia, Atmos. Environ., 36(31), 4895-4905, 2002.

Tao, Z. N. and Jain, A. K.: Modeling of global biogenic emissions for key indirect greenhouse gases and their response to atmospheric $\mathrm{CO} 2$ increases and changes in land cover and climate, J. Geophys. Res.-Atmos., 110, D21, doi:10.1029/2005JD005874, 2005 .
Thunis, P. and Cuvelier, C.: Impact of biogenic emissions on ozone formation in the Mediterreanean area-a BEMA modelling study, Atmos. Environ., 34, 467-481, 2000.

Tie, X., Guenther, A., and Holland, E.: Biogenic methanol and its impacts on tropospheric oxidants, Geophys. Res. Lett., 30, 17, doi:10.1029/2003GL017167, 2003.

Tsigaridis, K. and Kanakidou, M.: Global modelling of secondary organic aerosol in the troposphere: a sensitivity analysis, Atmos. Chem. Phys., 3, 1849-1869, 2003, mboxhttp://www.atmoschem-phys.net/3/1849/2003/.

Villanueva-Fierro, I., Popp, C. J., and Martin, R. S.: Biogenic emissions and ambient concentrations of hydrocarbons, carbonyl compounds and organic acids from ponderosa pine and cottonwood trees at rural and forested sites in Central New Mexico, Atmos. Environ., 38(2), 249-260, 2004.

Wang, K. Y. and Shallcross, D. E.: Modelling terrestrial biogenic isoprene fluxes and their potential impact on global chemical species using a coupled LSM-CTM model, Atmos. Environ. 34(18), 2909-2925, 2000.

Went, W.: Blue hazes in the atmosphere, Nature, 187, 641-643, 1960.

Westberg, H., Lamb, B., Hafer, R., Hills, A., Shepson, P., and Vogel, C.: Measurement of isoprene fluxes at the PROPHET site, J. Geophys. Res., 106(D20), 24 347-24 358, 2001.

Wiedinmyer, C., Guenther, A., Harley, P., Hewitt, N., Geron, C., Artaxo, P., Steinbrecher, R., and Rasmussen, R.: Global organic emissions from vegetation, Emissions of atmospheric trace compounds, edited by: Granier, C., Artaxo, P., and Reeves, C. E., Dordrecht, The Netherlands, 115-170, 2004. 